\title{
Taxonomy, biostratigraphy and biofacies of an Upper Ordovician (Katian) conodont fauna from the Casaio Formation, Northwest Spain
}

\author{
Gustavo G. Voldman \& José M. Toyos
}

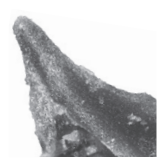

\begin{abstract}
Although Katian conodont faunas from high-latitude Gondwanan to peri-Gondwanan regions are widely referred to in the literature, their taxonomy is not yet stabilised, which is critical to biostratigraphically constrain the climate and tectonic events preceding the Hirnantian mass-extinction. In the present contribution, 595 conodont elements and abundant fragmentary conodont material recovered from meta-limestones of the Casaio Formation, northern Central Iberian Zone, is taxonomically and biostratigraphically analysed. The conodont assemblage is characterised by the genera Amorphognathus, ?Baltoniodus, ?Drepanoistodus, "Drepanodus", Eocarniodus, Hamarodus, Icriodella, Istorinus, Panderodus, Sagittodontina, Scabbardella, and Walliserodus, and documents the lower Amorphognathus ordovicicus Zone (Ka3) in Northwest Spain. After the taxonomic analysis, Icriodella iberiensis sp. nov. is proposed, and the complexity of the balognathid genera Sagittodontina and Amorphognathus is further discussed. Based on the composition of the major components, a new Icriodella-Sagittodontina-Amorphognathus Biofacies is introduced. Conodont based correlations and cluster analysis verify the strong similarity of the conodont assemblage of the Casaio Formation with the Thuringian conodont faunas from the Upper Ordovician Mediterranean Province. - Key words: conodont, taxonomy, biostratigraphy, biofacies, Central Iberian Zone, Spain, Katian, Ordovician.
\end{abstract}

Voldman, G.G. \& Toyos, J.M. 2019. Taxonomy, biostratigraphy and biofacies of an Upper Ordovician (Katian) conodont fauna from the Casaio Formation, Northwest Spain. Bulletin of Geosciences 94(4), 455-478 (11 figures, 1 table). Czech Geological Survey, Prague. ISSN 1214-1119. Manuscript received May 23, 2019; accepted in revised form November 14, 2019; published online December 31, 2019; issued December 31, 2019.

Gustavo G. Voldman, CICTERRA (CONICET-UNC), CIGEA, Universidad Nacional de Córdoba, Córdoba, Argentina, gvoldman@unc.edu.ar •José M. Toyos, Instituto Geológico y Minero de España, Unidad de León, 24006 León, Spain

Ordovician high-latitude Gondwanan and peri-Gondwanan regions are characterised by siliciclastic deposition under mostly shallow, cold-water regimes. These vast regions, currently represented by central southern Europe and North Africa, experienced a major environmental change during the Late Ordovician with the abrupt appearance of calcareous deposits of highly variable thickness (e.g. Villas et al. 2002, Boucot et al. 2003). The limestone deposition was associated either with a sharp climatic global warming named as Boda Event after the Boda Limestone of Sweden (Fortey \& Cocks 2005), or with a general cooling (Cherns \& Wheeley 2007). Currently, the Late Ordovician (Katian-Hirnantian) through earliest Silurian (Rhuddanian) time interval is regarded as a period of variable climate and sea level conditions, with at least two separate pulses of glacial advance and one of retreat during a late Katian global warm interval (Melchin et al. 2013, Ghienne et al. 2014, Kröger et al. 2017). The latter cooling triggered widespread marine anoxia by reorganisation of the thermohaline circulation, which resulted in the second pulse of the Hirnantian mass extinction, the first of the 'Big Five' Phanerozoic mass extinctions (Bartlett et al. 2018).

The pioneer study by Fuganti \& Serpagli (1968) on the Katian fauna of the Urbana Limestone of the Central Iberian Cordillera started the Ordovician conodont studies in the Iberian Peninsula (Fig. 1). Since then, several conodont studies have focused on the Upper Ordovician limestones present in the different tectonometamorphic domains of Spain (summarised by Sarmiento et al. 2011). Particularly, the common record of conodonts of the Amorphognathus ordovicicus Zone (Ka3-4 time slices of Bergström et al. 2009) has allowed correlation of the the Urbana Limestone with the Cystoid Limestone in the Eastern Iberian Cordillera, the 'Pelmatozoan Limestone' in the Ossa-Morena Zone, the 'unidad calcárea superior' in the Cantabrian Zone, the Estana Formation in the Pyrenees, and the Ferradosa Formation from the Portuguese Central Iberian Zone (e.g. Hafenrichter 1979; Sarmiento 1990, 1993, 2002; Sarmiento et al. 2001; del Moral 2003, 2007; del Moral \& Sarmiento 2008). 

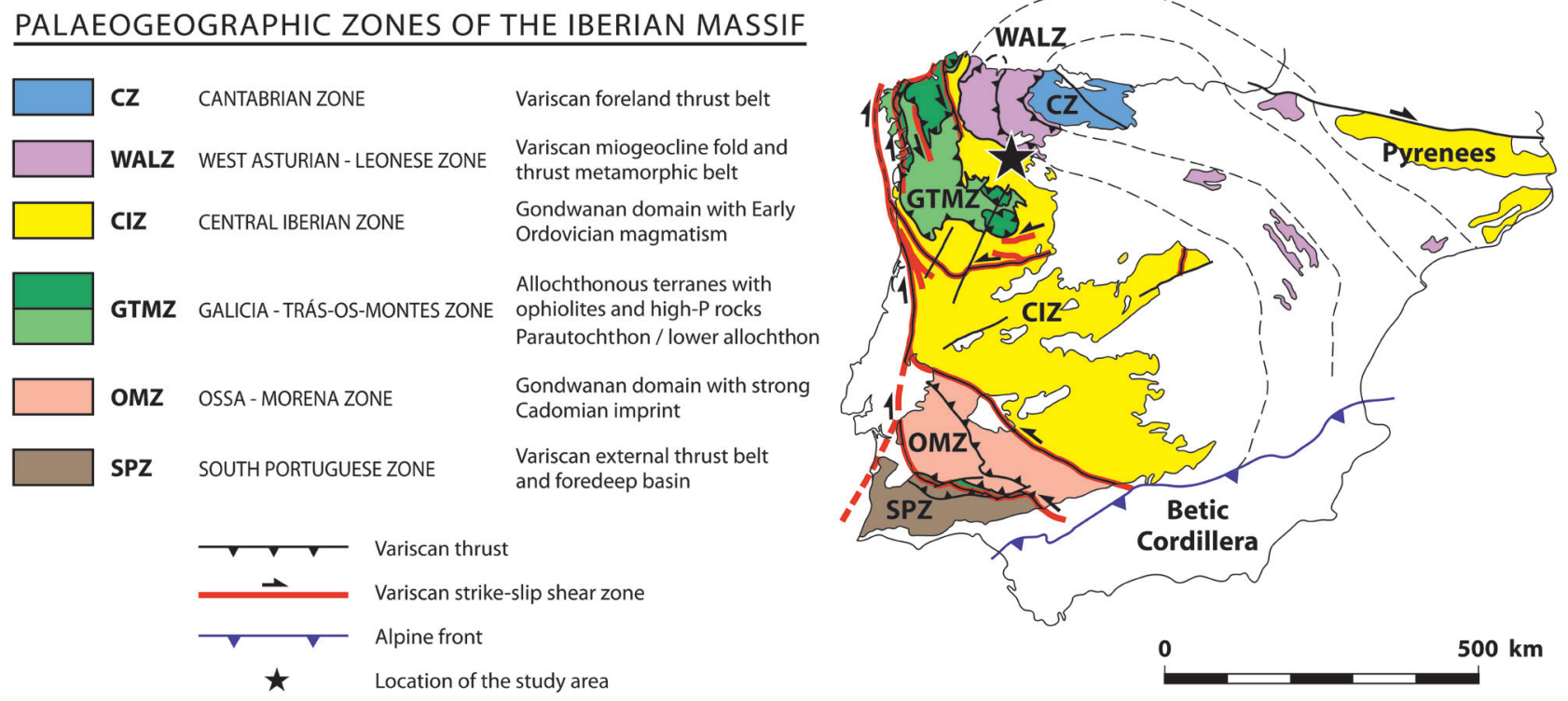

Figure 1. Tectonic map of the Iberian Massif including the different palaeogeographic zones (modified from Martínez Catalán 2011 and RodríguezCañero et al. 2018).

In contrast, Ordovician conodont studies in NW Spain are scarcely developed due to the absence of favourable facies and the pervasive Variscan metamorphism with cleavage that affected the region. The landmark study by Sarmiento et al. (1999) improved the Upper Ordovician conodont biostratigraphic scheme of the northern Central Iberian Zone, by documenting the Amorphognathus ordovicicus Zone in the Casaio Formation, the Aquiana Limestone, and in calcareous pebbles of the glacial-related Rozadais Formation.

In the present contribution, we analyse a conodont assemblage from the Casaio Formation, characterised by specimens referable to the genera Amorphognathus, ?Baltoniodus, ?Drepanoistodus, "Drepanodus", Eocarniodus, Hamarodus, Icriodella, Istorinus, Panderodus, Sagittodontina, Scabbardella, and Walliserodus. The conodont assemblage documents the A. ordovicicus Zone in the Casaio Formation and, despite being strongly affected by Barrovian metamorphism, the recovered specimens allowed a detailed taxonomical analysis, shedding light on the poorly known Upper Ordovician conodont faunas from the northern Gondwanan margin.

\section{Geological setting}

A thick passive margin succession accumulated on the northern margin of Gondwana during the Early Palaeozoic, subsequent to the opening of the Rheic Ocean (e.g. Aramburu et al. 2002). Its rift-drift transition is temporally constrained by the widespread Lower Ordovician magmatism disseminated throughout NW
Iberia, especially in the "Ollo de Sapo" volcanic belt in the northern area of the Central Iberian Zone (Fig. 1). The Upper Ordovician succession is generally characterised by alternating shales, siltstones and sandstones overlain by limestones and glaciomarine diamictites (e.g. GutiérrezMarco et al. 2002). According to U-Pb detrital zircon provenance data, the passive margin of NW Iberia was situated close to the palaeoposition of central North Africa and the Saharan Craton, remaining relatively stable at least from the Ordovician until the onset of the collision between Gondwana and Laurussia in the Late Devonian (Pastor Galán et al. 2013). Successively, the Lower Palaeozoic deposits in Iberia were involved in the Variscan Orogeny, associated with metamorphism, erosion and the oroclinal buckling of an originally near-linear convergent margin (e.g. Nance et al. 2012).

The Casaio Formation (Barros Lorenzo 1989) comprises a meta-sedimentary succession $60-100 \mathrm{~m}$ thick, consisting of metasandstone, quartzite and slate cropping out near Casaio (Ourense, Galicia), overlying the essentially Darriwilian Luarca Formation (GutiérrezMarco et al. 1999), and overlain either by the Rozadais Formation in the Truchas Syncline or the Aquiana Limestone in the Caurel-Peñalba Syncline (Sarmiento et al. 1999). It contains several calcareous intercalations, up to $4 \mathrm{~m}$ in thickness, informally known as Trigal limestones (Gutiérrez-Marco et al. 1988), which crop out discontinuously along both flanks of the Truchas Syncline and, locally, in the northern flank of the Teleno Anticline. The scarce palaeontological data from the Casaio Formation derives from these calcareous levels. Accordingly, Gutiérrez-Marco et al. (1996) reported 
a diverse pelmatozoan association (Cyclocharax paucicrenellatus, Trigonocyclicus $\mathrm{cf}$. vajgatschensis, Cyclocyclicus sp., and undetermined cystoids), analogous to the one present in the Aquiana Limestone.

Sarmiento et al. (1999) documented Hamarodus, Sagittodontina, and Scabbardella from the Trigal limestones, and referred them to the lower part of the A. ordovicicus Zone based on the record of Amorphognathus sp. and Sagittodontina robusta in the overlying Aquiana Limestone at La Chana section, and regional stratigraphic correlation. However, the highly variable thicknesses $(0-300 \mathrm{~m})$ of the Aquiana Limestone over a few $\mathrm{km}$ of distance may involve diachronic carbonate deposition, as observed in the Upper Ordovician sedimentary successions of the Baltic Basin (e.g. Kröger et al. 2017). In the present contribution, we verify the age proposed by Sarmiento et al. (1999) for the Trigal limestones by direct means, based on a larger conodont collection, and the partly cartographic lateral stratigraphic correlation of the Casaio Formation with the Aquiana Limestone (e.g. Gutiérrez-Marco et al. 1988), supported by detailed cartographic work.

\section{Material and methods}

The current conodont collection is derived from outcrops of the Trigal limestones of the Casaio Formation located $1.5 \mathrm{~km}$ E of Yeres, along the pathway to Orellán (Figs 2, 3). In this section, the Trigal limestones are characterised by $2.2 \mathrm{~m}$ of ferruginous meta-siltstone, followed above by $7.2 \mathrm{~m}$ of meta-bioclastic limestone, in beds $3-25 \mathrm{~cm}$ in thickness, and partly dolomitised. The described succession has a lenticular shape and is contained within grey slates of the Casaio Formation. Five exploratory meta-limestone samples (samples CA, Fig. 2) were

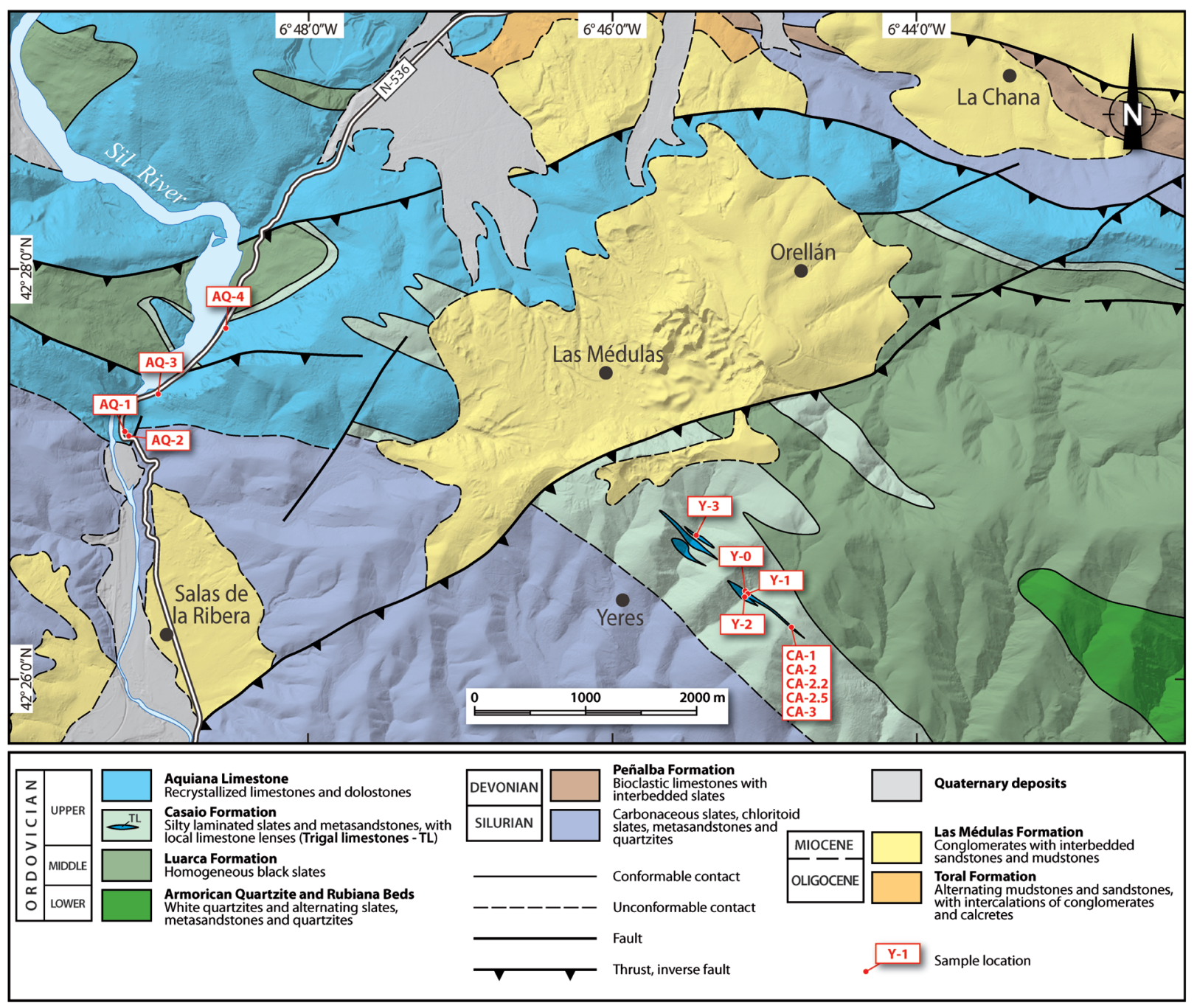

Figure 2. Geological map of the study area with sampled points (modified from Rodríguez Fernández et al. in press). 
Table 1. Conodont samples and numerical distribution of species from the Trigal limestones of the Casaio Formation.

\begin{tabular}{|c|c|c|c|c|c|c|c|c|}
\hline Sample & CA1 & CA2 & CA2.2 & CA2.5 & CA3 & Y1 & Y3 & Total \\
\hline Weight $(\mathrm{g})$ & 3500 & 5600 & 11500 & 2500 & 3550 & 2100 & 4200 & 32950 \\
\hline \multicolumn{9}{|c|}{ Amorphognathus ordovicicus Branson \& Mehl } \\
\hline M & & & 4 & & & & & 4 \\
\hline $\mathrm{Pa}$ & & & 53 & & & & 2 & 55 \\
\hline $\mathrm{Pb}$ & & 5 & 31 & & & & & 36 \\
\hline $\mathrm{Sa}$ & & & 1 & & & & & 1 \\
\hline $\mathrm{Sb}$ & & & 1 & & & & & 1 \\
\hline $\mathrm{Sc}$ & & & 3 & & & & & 3 \\
\hline $\mathrm{Sd}$ & & & & & & 1 & & 1 \\
\hline
\end{tabular}

$\mathrm{Pb}$

?Baltoniodus sp. nov. A

\begin{tabular}{llll}
$\mathrm{Pa}$ & 5 & 5 \\
$\mathrm{~Pb}$ & 2 & 5 & 7 \\
$? \mathrm{M}$ & 1 & & 1 \\
\hline "Clavohamulus sp. 1" Knüpfer & 8 & 8 \\
\hline "Drepanodus suberectus" Rexroad & 2 & 2 \\
\hline
\end{tabular}

"Drepanoistodus cf. suberectus" (Branson \& Mehl)

$\mathrm{M}$

$P$

$\mathrm{S}$

?Drepanoistodus sp.

$\underline{\mathrm{S}}$

"Eocarniodus" aff. gracilis (Rhodes)

1 - 1

5

12

$11 \quad 1$

Hamarodus brevirameus (Walliser)

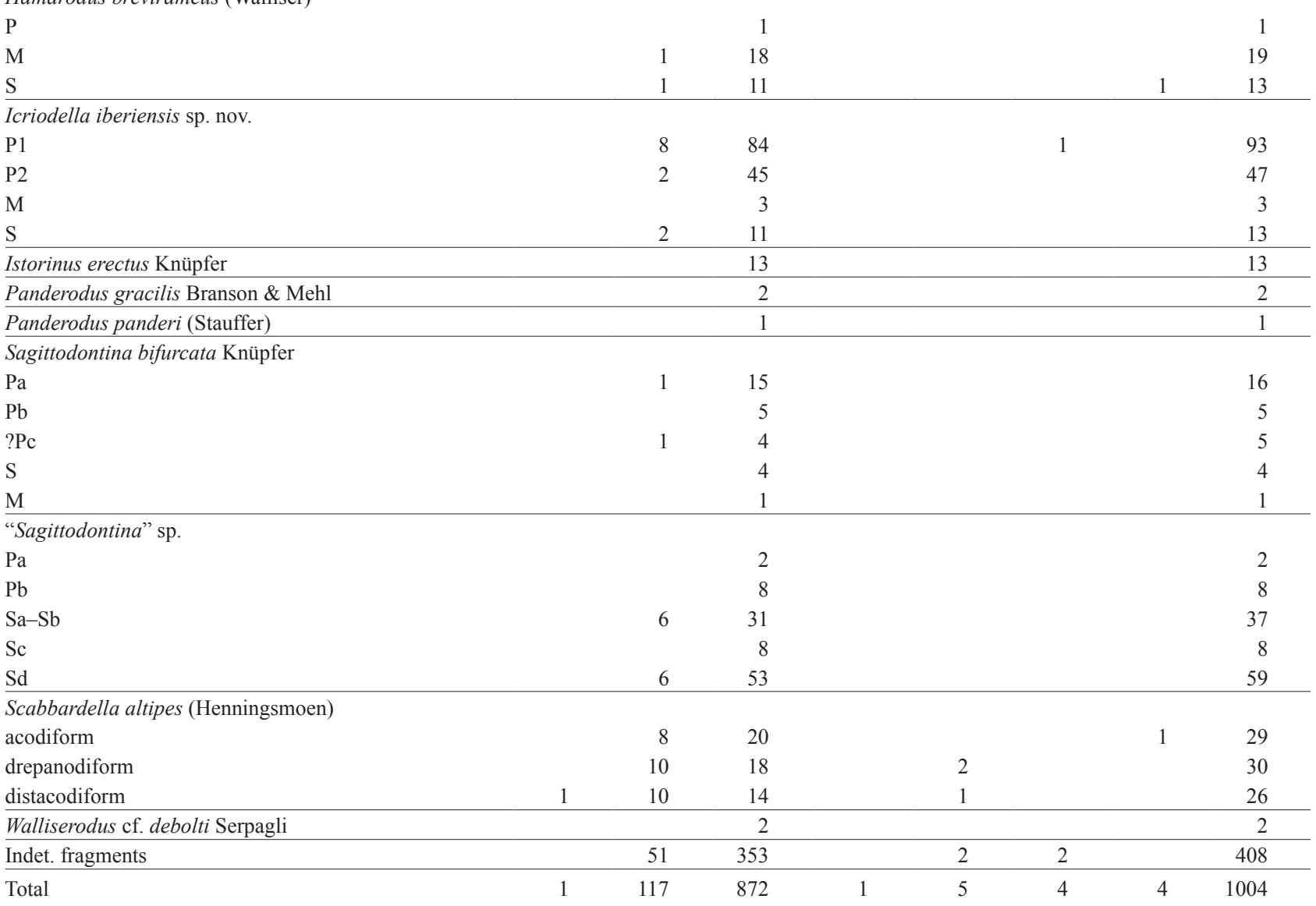


processed in buffered acetic acid following the standard techniques (Jeppsson et al. 1985, Stone 1987). All of the rock samples yielded conodonts, which led to further intensive resampling, conditioned by their productivity and availability in the outcrops. After processing a total rock weight of $26.6 \mathrm{~kg}, 589$ conodont elements and hundreds of undeterminable fragments were recovered (Tab. 1). Within the insoluble residue, iron oolites were also recovered. Additionally, four exploratory samples were obtained from a complementary section (samples $\mathrm{Y}, 9.5 \mathrm{~kg}$ total rock weight), where the upper level of the Trigal limestones is overlain by a dm-scale ferruginous bed, and four other samples from outcrops of the Aquiana Limestone along the $\mathrm{N}-536$ route (samples AQ, $12 \mathrm{~kg}$ total rock weight), though they were almost barren of microfossils (Tab. 1), probably reflecting a stronger grade of recrystallisation and dolomitisation towards the west. Conodont elements are uniformly grey (CAI 6), which indicates palaeotemperatures in the range of $360-550^{\circ} \mathrm{C}$ following the calibration of Rejebian et al. (1987), consistent with the greenschists facies of the siliciclastic sediments in the area. Conodont elements are often ductile deformed, showing cleavage and frequent iron stains. Given the metamorphism that affects the Casaio Formation, the possible preservation of the conodont elements in the meta-limestones appears to be related to the high organic matter content (Epstein et al. 1977) and impurities of the meta-limestones, which can delay thermal maturation and degradation.
The conodont specimens are housed in the Museo Geominero (IGME) of Spain, under repository codes MGM-8207O to MGM-8213O. Conodont images were obtained with a Zeiss Axiocam 506 camera attached to an Axio Scope A1 petrographic microscope (Departamento de Geología, Universidad de Oviedo) and an Olympus LEXT OLS4000 confocal laser microscope (LAMARX, Universidad Nacional de Córdoba). Image stacking was conducted with Zerene Stacker and Adobe Photoshop. SEM imaging was avoided due to the mounting risks of the delicate, metamorphosed conodont elements.

\section{Biostratigraphy and biofacies}

The conodont collection from the Casaio Formation is quantitatively dominated by four genera: Icriodella (26\%), Sagittodontina (24\%), Amorphognathus (17\%), and Scabbardella (14\%) (excluding the undeterminable deformed or broken fragments). Less frequent are Hamarodus (6\%), and rarely ?Drepanoistodus, ?Baltoniodus, Istorinus, “Clavohamulus", Panderodus, Eocarniodus, and Walliserodus, which combine for the remaining $13 \%$ of the assemblage (Fig. 4). Based on its composition, the Casaio conodont fauna is ascribed to the Mediterranean Province of Sweet \& Bergström (1984), with locally abundant faunas of low diversity, characteristic of Late Ordovician polar to subpolar regions. It shares the typical species association of the

\section{NW}

\section{SE}

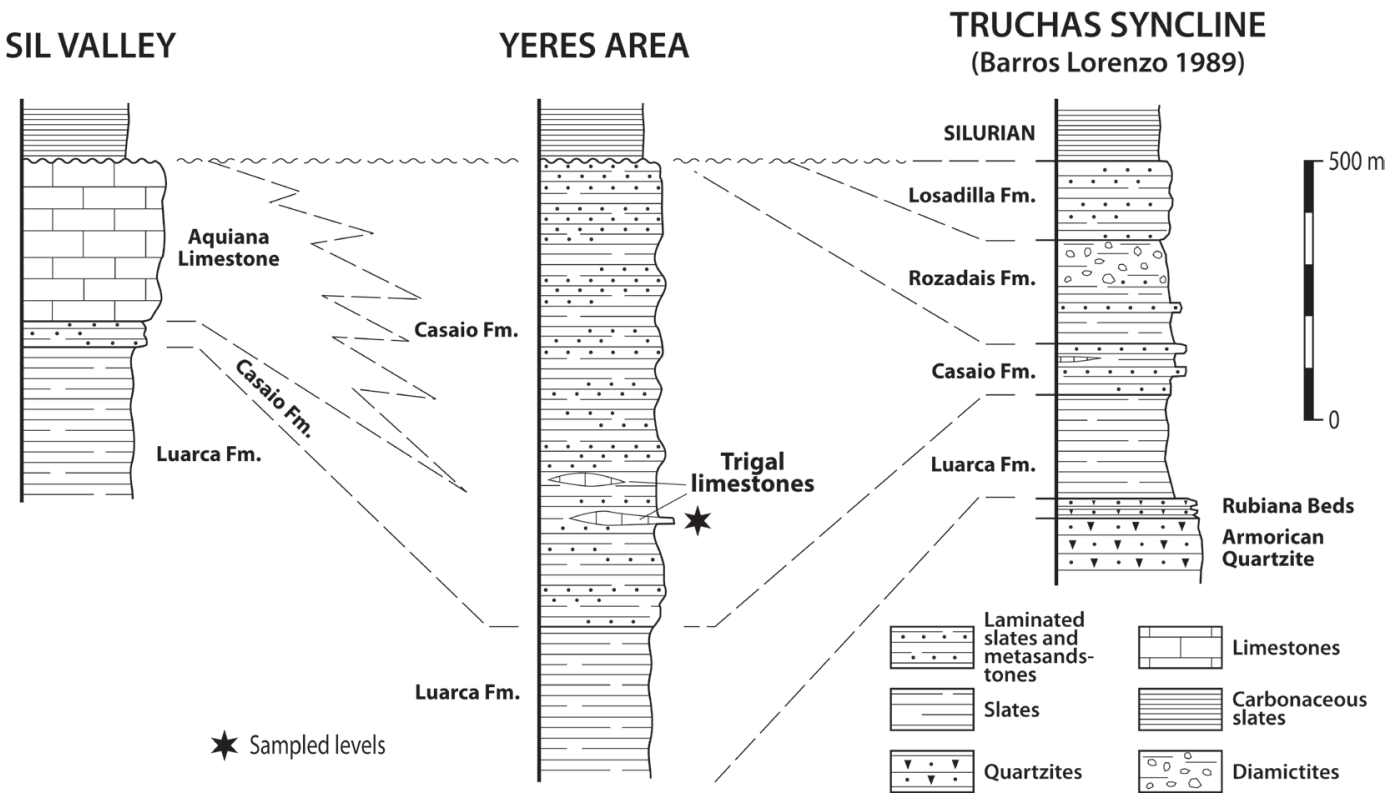

Figure 3. Schematic stratigraphic columns for the Ordovician in the study area, with the position of samples in the Trigal limestones of the Casaio Formation (northern Central Iberian Zone). 
Sholeshook

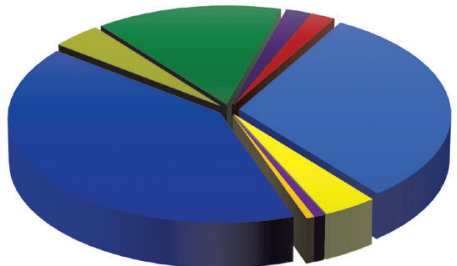

Caliza Urbana

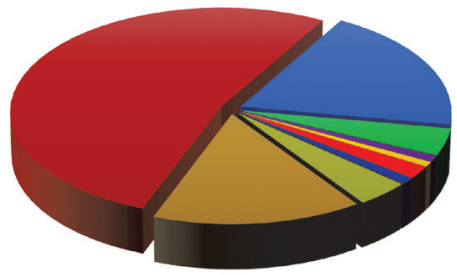

Siljan

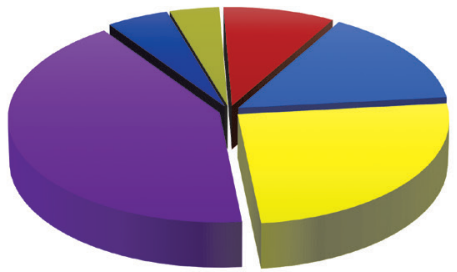

Keisley Limestone

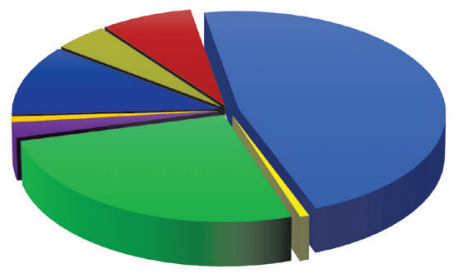

Amorphognathus

Dapsilodus

Eocarniodus

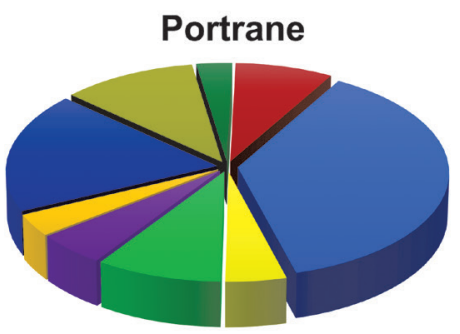

Casaio Formation

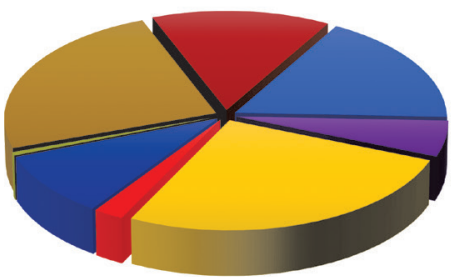

Sardinia

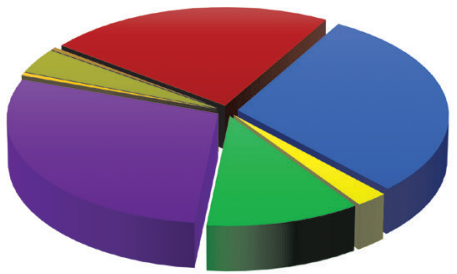

Kalkbank

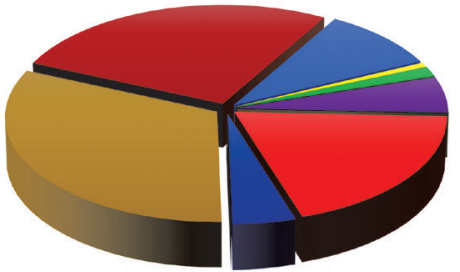

Hamarodus

Icriodella

Istorinus

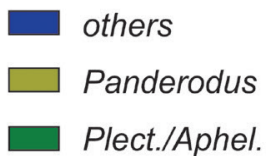

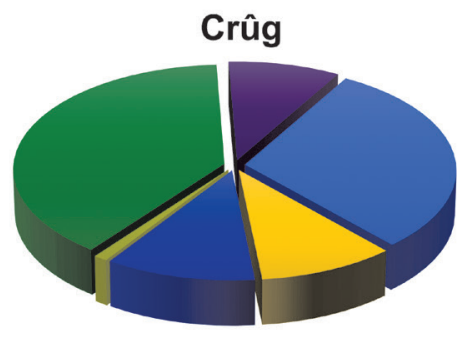

Cautley

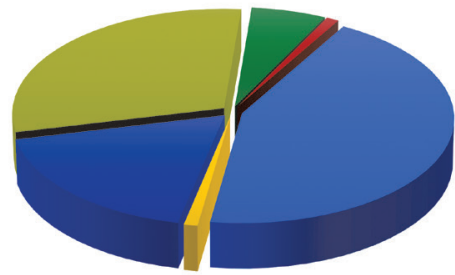

Uqua Formation

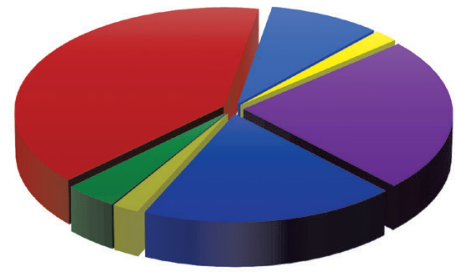

lowa

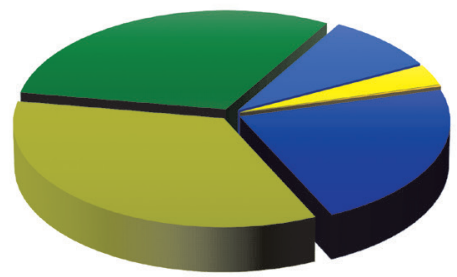

Rhodesognathus

"Sagittodontina"

Scabbardella

Figure 4. Pie charts with relative abundance of conodont genera in the lower Amorphognathus ordovicicus Zone of regions discussed in the text (see text for references).

Sagittodontina robusta-Scabbardella altipes Biofacies, which is known from Thuringia (Knüpfer 1967, Fuchs 1990, Ferretti \& Barnes 1997), Libya (Bergström \& Massa 1992), Portugal (Sarmiento et al. 2001), Spain (Carls 1975, Sarmiento et al. 2011, and references therein), and NW France (Paris et al. 1981, Ferretti et al. 2014a), though with a different frequency distribution of the conodont species. The Carnic Alps, an important sector of the peri-Gondwana Mediterranean Province characterized by the Hamarodus europaeus-Dapsilodus mutatus-
Scabbardella altipes Biofacies (Serpagli 1967, Bagnoli et al. 1988, Ferretti \& Schönlaub 2001), is linked with the conodont assemblage from the Casaio Formation by the common occurrence of Amorphognathus, Drepanoistodus, Hamarodus, Icriodella, Panderodus, Sagittodontina and Scabbardella.

Icriodella is generally a rare component of the $\mathrm{Sa}$ gittodontina robusta-Scabbardella altipes Biofacies in Baltoscandia (Fig. 4), except during occasional immigration pulses (Sweet \& Bergström 1984). Conversely, it 
is far more frequent in the Late Ordovician warm-water environments of the British Isles, characterised by the Amorphognathus-Plectodina Biofacies, where it may comprise up to $10 \%$ of the faunal assemblage as in the Crûg Limestone (Lindström 1959, Orchard 1980, Savage $\&$ Bassett 1985). Icriodella and Panderodus are typical components of Late Ordovician-Llandovery shallowshelf biofacies (Aldridge \& Jeppsson 1984, Sweet \& Bergström 1984, Watkins \& Kuglitsch 1997, Barnes 2019). The slightly older (Oandu Stage) Phragmodus undatus-Icriodella-Plectodina Biofacies of Baltoscandia is characterised by warm-water conodont taxa associated with bahamitic limestones (Sweet \& Bergström 1984). The ubiquitous general distribution of the coniform genera Panderodus and Drepanoistodus in the Vauréal Formation of Anticosti Island, Quebec, is prone to reflect its pelagic habit of life (Nowlan \& Barnes 1981, Barnes 2019).

In the North American Late Ordovician, Amorphognathus species are frequently associated with rather deep water deposits (e.g. Sweet \& Bergström 1984). For instance, the shallow shelf facies of the Midcontinent Realm in the Canadian Shield, characterised by Oulodus, Aphelognathus, Plectodina, Phragmodus and Rhipidognathus, records brief invasions of Amorphognathus, Icriodella and Periodon (North Atlantic Province species), at times of maximum transgression of cooler Iapetus waters (Sweet et al. 1971, Barnes \& Fåhræus 1975, Barnes 2019). However, Amorphognathus species in the Vauréal Formation follow an opposite pattern, with a much higher abundance in inner sublittoral than outer sublittoral environments (Zhang et al. 2006). As Amorphognathus is also common in distal, graptolite-bearing environments of the Baltic region, it is possible that the distribution of Amorphognathus was more dependent on water temperature than on water depth. This is supported by the general palaeogeographic distribution of the Katian conodont faunas, as distant regions with variable environments may share fairly similar conodont assemblages (e.g. Sweet \& Bergström 1984).

Based on the possible stenothermal character of Icriodella, the Icriodella-Sagittodontina-Amorphognathus Biofacies here proposed may either represent a migration episode associated with climate amelioration in the polar to circumpolar regions (e.g. early Boda warming sensu Melchin et al. 2013) or, alternatively, a lower latitude

Figure 5. Upper Ordovician conodont biostratigraphic scheme of Iberia-Bohemia (South Gondwana) indicating the position of the Trigal limestones of the Casaio Formation, and its global correlation with the conodont successions established in other palaeogeographic domains. Compiled after Gutiérrez-Marco et al. (2017), Zhen \& Percival (2017) and Zhang (2018), with the stage slices of Bergström et al. (2009) and the Ordovician Time Scale of Cooper et al. (2012).

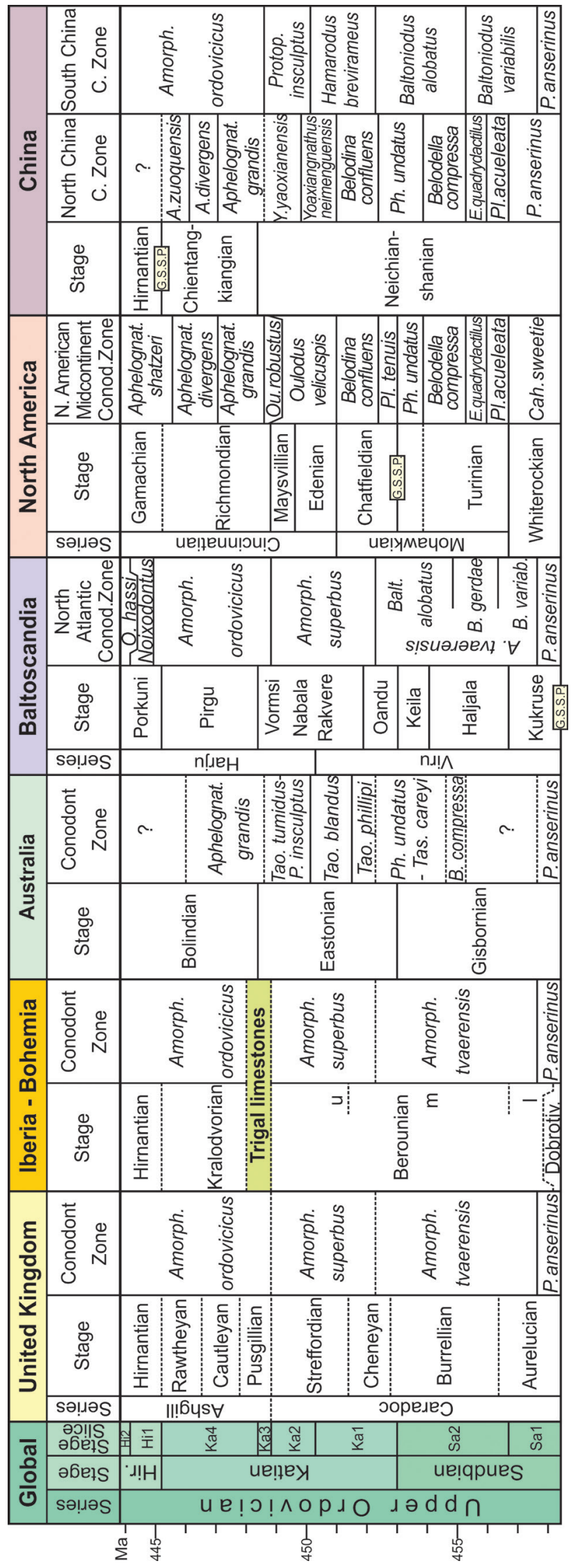


palaeogeographic position for the northern Central Iberian Zone within the northern Gondwanan margin. Accordingly, the glacial-related Rozadais Formation, which overlies the Casaio Formation in the Truchas Syncline, includes cryptostomate bryozoan in calcareous pebbles that suggest relatively warm waters, and resemble others assemblages recovered in NW France, Germany, Argentina, and the Pelmatozoan Limestone of the OssaMorena Zone (N. Spjeldnaes in Sarmiento et al. 1999).

The record of $A$. ordovicicus in the Trigal limestones of the Casaio Formation implies deposition during the homonymous biozone, of late Katian age (Ka3-Ka4, Fig. 5). Refinement of the age comes from the composition of the conodont assemblage, which allows for biostratigraphic correlation with the Kalkbank of Thuringia (Knüpfer 1967, Fuchs 1990, Ferretti \& Barnes 1997), and the broadly coeval Sholeshook Limestone of Wales, which Ferretti et al. (2014b) assigned to the lower A. ordovicicus Zone, in agreement with previous trilobite, graptolite, and chitinozoan data (Fig. 5). Specifically, additional time constraints are provided by Icriodella iberiensis sp. nov., which occurs in the upper levels of the "Bancos Mixtos", provisionally assigned to the A. superbus Zone (del Moral $\&$ Sarmiento 2008), and to the A. superbus Zone of the Nabiullino Formation of the Southern Urals (Mavrinskaya \& Yakupov 2016). It is also associated with typical conodont assemblages of the $A$. ordovicicus Zone in the Urbana Limestone of the southern Central Iberian Zone (del Moral \& Sarmiento 2008), and of the Sholeshook Limestone of Wales (Ferretti et al. 2014b). A thorough revision of the collections containing Icriodella iberiensis sp. nov. would help to refine its specific biostratigraphical range and geographical dispersion.

The rare occurrence of warm-water Panderodus in our samples is consistent with the opposite large contributions of the cold-water Scabbardella, as observed in the upper part of the Mójcza succession (Dzik 1998). On the other hand, Hamarodus brevirameus (Walliser 1964) is widely distributed, though with variable abundance, in Late Ordovician rocks from Europe (Bergström \& Ferretti 2014). It is also scarcely represented in the North American Midcontinent domain (Ferretti et al. 2014b), whereas it characterises the early Katian in South China (Wang et al. 2019). Dapsilodus, a coniform genus generally present in the Katian successions from Baltoscandia, the British Isles and North America, is absent in our samples and in the meridional outcrops of the Central Iberian Zone (del Moral \& Sarmiento 2008).

A Q-mode cluster analysis of conodonts at generic level $(n=35)$ from the Casaio Formation, the Urbana Limestone from the southern Central Iberian Zone (del Moral \& Sarmiento 2008), the Kalkbank of Thuringia (Ferretti \& Barnes 1997), southern Sardinia (Ferretti \& Serpagli 1991, 1998), the Uqua Formation of the Carnic Alps (Serpagli
1967, Bergström \& Ferretti 2014), the upper Slandrom Limestone of Siljan (south-central Sweden, Baltoscandia; Ferretti et al. 2014b), the Sholeshook and Crûg limestones from South Wales (Savage \& Bassett 1985, Ferretti et al. 2014b), the Cautley Mudstone (Orchard 1980) and the Keisley Limestone (Bergström \& Ferretti 2014) of $\mathrm{N}$ England, and the Portrane Limestone from Ireland (Ferretti et al. 2014c) is presented in Fig. 6. Among the conodont faunas from the regions listed above, we use for comparison the North American faunas from the upper Dubuque Formation from Iowa (Red River Province; Ferretti et al. 2014b) and the Vauréal Formation of the Anticosti Island, eastern Canada (Nowlan \& Barnes 1981). Clustering was conducted using the UPGMA method and the Jaccard index was adopted to measure similarity $(\mathrm{c}=0.90)$.

The algorithm numerically confirms the strong similarity of the conodont assemblage from the Casaio Formation to the Thuringian conodont faunas and, to a lesser extent, to the faunas present in the Urbana Limestone and Sardinia (Fig. 6), all of them characteristic of the Mediterranean Province of the North Atlantic Realm (Sweet \& Bergström 1984, Ferretti \& Serpagli 1998). The British Province conodont faunas (Cautley, Keisley, Portrane, Sholeshook) cluster along with those from Siljan (Baltoscandia Province), exhibiting a considerable similarity for the North Atlantic Realm. The conodont fauna from the Uqua Formation of the

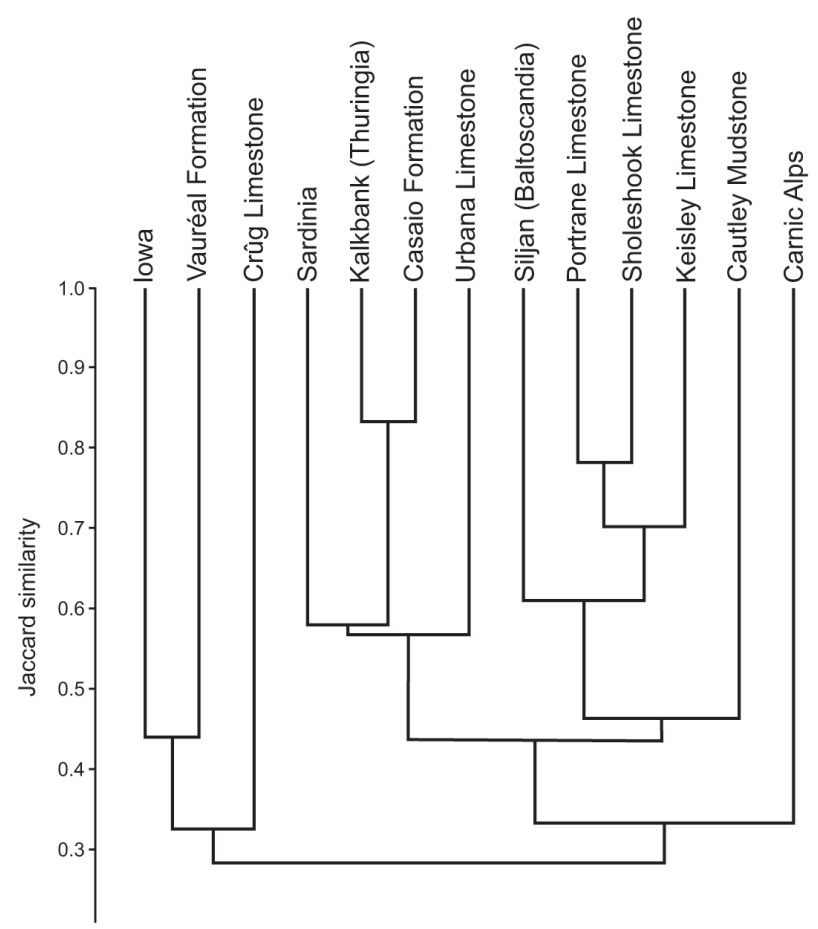

Figure 6. Cluster analysis (UPGM) of Katian localities at genera level (see text for references). 
Carnic Alps (Mediterranean Province) occurs associated with both the British and Baltoscandia provinces as well, verifying previous affinity observations (Ferretti \& Serpagli 1998). On the other hand, the low-latitude North American Midcontinent Realm (Sweet \& Bergström 1984, Bergström \& Ferreti 2014) is represented by the conodont faunas from Iowa and Anticosti, which cluster along with those from the British Crûg Limestone.

\section{Systematic palaeontology}

The conodont species obtained from the Trigal limestones of the Casaio Formation, and their frequency per sample, are listed in Tab. 1. Many of the species are well-known taxa so only a short comment with the Linnean taxonomy is provided, along with illustrations of representative conodont elements. Note that only key identifications and most recent review studies are given in the synonymy lists.

Phylum Chordata Bateson, 1886

Class Conodonta Eichenberg, 1930

Order Belodellida Sweet, 1988

Family Belodellidae Khodalevich \& Tschernich, 1973

\section{Genus Walliserodus Serpagli, 1967}

Type species. - Acodus curvatus Branson \& Branson, 1947.

\section{Walliserodus cf. debolti Serpagli, 1967}

Figure $7 \mathrm{~K}, \mathrm{O}$

Remarks. - Two acodiforms, with a nearly symmetrical conspicuous costa on each lateral side, keeled anterior and posterior margins, and laterally flattened, were recovered in our material. These elements resemble the specimen illustrated by Serpagli (1967) as W. debolti (Rexroad) s.f. (pl. 31, fig. 1a-c). Cooper (1975) described Walliserodus curvatus in terms of multielement taxonomy, consisting of Acodus curvatus s.f. Branson and Branson, Paltodus debolti s.f. Rexroad and other form species. He also observed that $W$. debolti (Rexroad) sensu Serpagli shows great morphologic variability and suggested that it is probably more primitive than $W$. curvatus.

Order Prioniodontida Dzik, 1976

Family Balognathidae Hass, 1959

Remarks. - Several important genera are included within this family and merit brief discussion based on our collections. For instance, different criteria have been proposed to distinguish the different species of Amorphognathus. The specific differences are more pronounced in the holodontiform (M) element, yet it is underrepresented in our samples. Savage \& Bassett (1985) analysed A. superbus from Rhodes' (1953) type localities of the Cymerig Limestone, noting that $\mathrm{M}$ elements were rare and more plastic than earlier suspected. They proposed taking into account the morphology of the $\mathrm{Pb}$ elements to help to distinguish $A$. superbus from A. ordovicicus, as the $\mathrm{Pb}$ elements in the later are smaller and more robust than in earlier species of the genus. In A. superbus, Savage \& Bassett (1985) distinguished: a) sinistral $\mathrm{Pb}$ elements of large size, deeply excavated, and with a strongly sinuous aboral inner margin; and $\mathrm{b}$ ) dextral $\mathrm{Pb}$ elements with an inner aboral margin which is deeply indented but nonsinuous. Bergström \& Massa (1992) and Ferretti et al. (2014b) reassessed the morphological characteristics of the $\mathrm{M}$ element as the main basis for species distinctiveness in Amorphognathus, independent of its frequency of occurrence. Based on their Welsh collection, Ferretti et al. (2014b) recognised an evolutionary trend in the denticle location of the $\mathrm{M}$ element of Amorphognathus duftonus Rhodes, from a lateral position in stratigraphically older specimens to a postero-lateral one in younger specimens. Following this criteria, Bergström \& Ferretti (2014) concluded that Amorphognathus duftonus present in the Keisley Limestone represents the more advanced evolutionary stage.

On the other hand, the distinction between the $\mathrm{Pb}$ elements for the apparatus reconstructions of Sagittodontina and of Amorphognathus is not clearly established, producing a considerable level of confusion (see discussion by del Moral \& Sarmiento 2008). Bergström (1983, fig. 4) first proposed the apparatus of Sagittodontina bifurcata Knüpfer s.f. (Fig. 8C, E), based on Libyan specimens, and suggested a similar oral-architecture to Amorphognathus. Fuchs (1990) reconstructed the apparatus of Sagittodontina after analysing the original collection of Knüpfer (1967) and additional material from Thuringia. Bergström \& Massa (1992) discussed and illustrated the Libyan collection as Sagittodontina robusta (Fig. 8E), including the previous synonymy.

In the apparatus reconstruction of Sagittodontina bifurcata Knüpfer proposed by Dzik (1989), the morphotypes $S$. robusta Knüpfer, $S$. bifurcata Knüpfer, $S$. r. flammeus Knüpfer, S. separata Knüpfer, S. unidentata Knüpfer, Sagittodontus dentatus Ethington, S. robustus Rhodes, and Lonchodus sp. occupied the sp (Pa) position, whereas Ambalodus triangularis var. indentatus Rhodes (corrected genus name after Branson \& Mehl original designation) occupied the oz $(\mathrm{Pb})$ position (Fig. 8F). However, in the latter form species, the lateral process develops "at base of apical denticle" (Rhodes 1953), and not from the first denticle anterior to the cusp as illustrated by Dzik (1994, pl. 22, fig. 7). The later characteristic is instead more typical of Rhodesognathus (Bergström \& 
Sweet 1966). Previously, Orchard (1980) considered Ambalodus triangularis var. indentatus Rhodes (1953) as the $\mathrm{Pb}$ element in the oral reconstruction of $A$. superbus, a criterion followed by Savage \& Bassett (1985). Fuchs (1990) referred Ambalodus triangularis var. indentatus Rhodes sensu Knüpfer (1967) as the Pb element of Sagittodontina robusta. Both having a sinuous inner margin, the form species of Knüpfer (1967) is distinguished from Rhodes' holotype by the lack of basal ledge and the slightly larger anterior denticles.

Ferretti \& Barnes (1997) restudied after Knüpfer (1967) the Kalkbank conodont faunas of Thuringia with additional material and adopting multielement taxonomy. They described as Pa elements conodonts of rather different shapes belonging to "the morphogenus "Sagittodontina Knüpfer, 1967' with the cusp slightly inclined posteriorly", embracing specimens with a platform-like posterior process (pl. 4, fig. 2) or pyramidal-shaped elements devoid of denticles (pl. 4, fig. 9) in the same morphologic category, following previous criteria (Dzik 1989, Bergström \& Massa 1992). Ferretti \& Barnes (1997) noticed that their $\mathrm{Pb}$ elements (sinistral 'ambalodiform' elements, pl. 4, figs 5-7) in their reconstruction of Sagittodontina robusta could belong to a separate apparatus along with a dextral 'ambalodiform' element (pl. 2, figs 11-13) that was previously considered to belong to Rhodesognathus elegans. The $\mathrm{Pb}$ elements illustrated by Ferretti \& Barnes (1997) fit better with Ambalodus triangularis var. indentatus Rhodes (1953) as observed by del Moral \& Sarmiento (2008), whereas the 'ambalodiform' element is treated herein as part of the ?Baltoniodus sp. nov. A apparatus.

Bergström \& Massa (1992) suggested that Noixodontus might be a junior synonym of Sagittodontina based on the striking similarity of the $\mathrm{Sa}-\mathrm{Sd}$ and $\mathrm{M}$ elements. The authors also considered the remote possibility that, given the relatively small size of the Sagittodontina and Noixodontus collections, the Pa element included in the apparatus reconstruction of $S$. robusta could belong to another apparatus. Actually, the Libyan Pa element which they ascribed to Sagittodontina robusta (Bergström \& Massa 1992, pl. 1, figs 13, 14; Fig. 8E) differs from Sagittodontina bifurcata Knüpfer s.f. (Fig. 8C) in that the anterolateral process is markedly directed downwards, producing a sort of deflected bowed anticusp, and in that the anterior process is apparently bar-type, with subequal sized denticles, and not distally decreasing in height. According to Dzik (1998), it resembles rather an element of Rhodesognathus from the Mójcza Limestone. McCracken (1987) regarded Noixodontus as a valid genus based on additional morphologic differences of the $\mathrm{Pa}$ and $\mathrm{Pb}$ elements.

In a more recent contribution, del Moral \& Sarmiento (2008) provided an alternative apparatus reconstruction for
Sagittodontina, based on the southern Central Iberian Zone conodont collections. They suggested that Sagittodontina bifurcata Knüpfer s.f. corresponds with the Pa element whereas Sagittodontina unidentata Knüpfer s.f. represents the Pb morphotypes (Fig. 8C, D, G). Previously, del Moral (2007) also illustrated pastinate elements (interpreted as Sagittodontus dentatus Ethington sensu Knüpfer s.f., pl. 29 , figs 13, 16) as P elements of Sagittodontina robusta, without giving further details. Our specimens from the Casaio Formation fit well with del Moral \& Sarmiento's (2008) proposal, though the current level of knowledge impedes determining the full apparatus reconstruction for Sagittodontina, and we do not discard the possible presence of Pc or Pd morphotypes pairs in Sagittodontina as recognised in others balognathid natural assemblages (Aldridge et al. 1995, 2013).

On the other hand, given the poor preservation of our material, the number of S elements in Sagittodontina is probably overestimated by including ramiform elements of Amorphognathus with the proximal section broken. The latter could be clearly distinguished if they preserved the characteristic hindeodellid denticulation (though Bergström \& Leslie 2010, illustrated S-series elements devoid of it in late forms of $A$. ordovicicus from its type area.

Ferretti \& Barnes (1997) suggested that the fragments classified as Clavohamulus n. sp. 1 and 2 by Knüpfer (1967) probably represent broken ramiform processes of Sagittodontina. We agree in that they are probably fragmentary in origin, although is hard to assign them to a particular genus, as determined in our samples (Fig. 11I, J). Particularly, Clavohamulus sp. 1 Knüpfer has the cusp so strongly curved inwards that it reflects a different style of denticulation (note that the original term Clavohamulus designates an upper Furongian-lower Tremadocian genus). Dzik (1989) also suggested that Istorinus erectus Knüpfer (1967) may represent broken fragments of Sagittodontina, a proposal refuted by Bergström \& Massa (1992) and subsequent authors by the finding of complete specimens, as in our samples.

\section{Genus Amorphognathus Branson \& Mehl, 1933}

Type species. - Amorphognathus ordovicicus Branson \& Mehl, 1933.

\section{Amorphognathus ordovicicus Branson \& Mehl, 1933}

Figure $7 \mathrm{~A}-\mathrm{H}, \mathrm{J}, \mathrm{L}$

1999 Amorphognathus ordovicicus Branson \& Mehl. Sarmiento et al., pp. 490, 492, 494, pl. 1, figs 1-4.

2008 Amorphognathus ordovicicus Branson \& Mehl. - del Moral \& Sarmiento, pp. 210-216, pl. 5, figs 1-21 (full synonymy). 


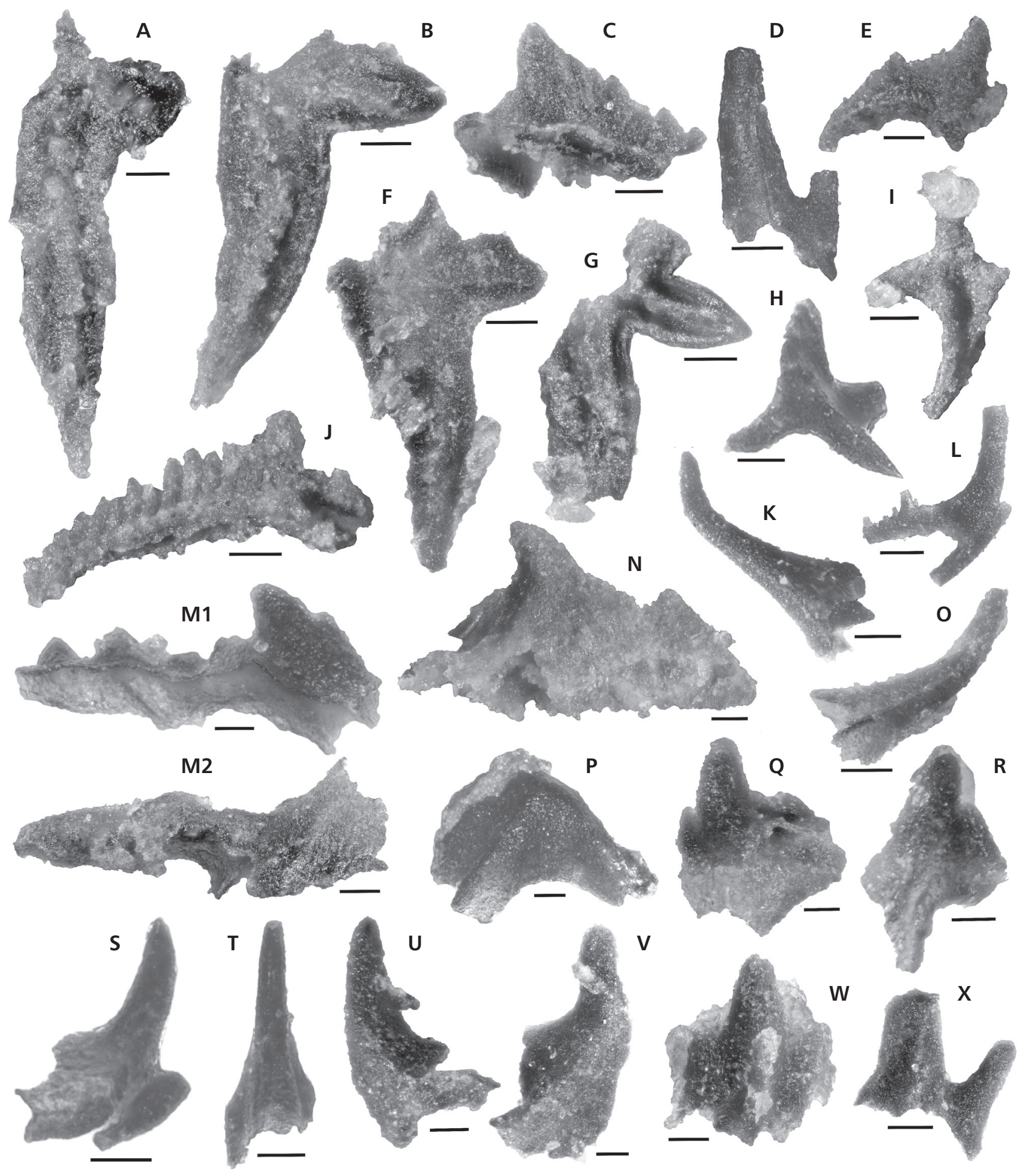

Figure 7. Late Katian conodonts from the Trigal limestones of the Casaio Formation, northern Central Iberian Zone. All elements are from sample CA2.2, except for V from sample CA2. • A-H, J, L, Amorphognathus ordovicicus Branson \& Mehl; A - Pa element, MGM-8209O-1; B - Pa element, MGM-8209O-2; C - blade of Pa element, MGM-8209O-3; D - M element, MGM-8209O-4; E - Pb element, MGM-8209O-5; F - Pa element, MGM-8209O-6; G - Pa element, MGM-8209O-7; H - Pb element, MGM-8209O-8; J - blade of Pa element MGM-8209O-9; L - Sc element, MGM-82090-10. • I - Amorphognathus sp. A del Moral, Pb element, MGM-8209O-11. • K, O - Walliserodus cf. debolti Serpagli; K MGM-8209O-12; O - MGM-8209O-13. - M-N, P-X - Sagittodontina bifurcata Knüpfer; M - Pa element, MGM-8209O-14; N - Pa element, MGM-8209O-15; P - Pa element, MGM-8209O-16; Q - Pa element, MGM-8209O-17; R - Pb element, MGM-8209O-18; S - Sb element, MGM-8209O-19; T - Sa element, MGM-8209O-20; U - ?Pc element, MGM-8209O-21; V - ?Pc element, MGM-8208O-1; W - ?M element, MGM-8209O-22; X- ?S element MGM-8209O-23. All scale bars are $100 \mu \mathrm{m}$. 
2014b Amorphognathus ordovicicus Branson \& Mehl. Ferretti et al., p. 819, figs 7o, 12a-e.

Remarks. - The M (holodontiform) elements recovered in our collection are distinguished by a robust, erect cusp, and an anterolateral process carrying a denticle (Fig. 7D). The prominent cusp and the poorly developed processes agree morphologically with the late Katian representatives of the species (Bergström \& Leslie 2010, Ferretti et al. $2014 b)$. Fragments of $\mathrm{Pa}$ elements are frequent in our samples, of both blade and non-blade types, as described by Bergström \& Sweet (1966). Dextral and sinistral Pb elements may vary largely in size and in the angle between the anterior and posterior processes. Denticulation in the posterior process of the $\mathrm{Pb}$ element may be of relatively uniform size or present a large denticle surrounded by smaller ones (Fig. 7E).

\section{Amorphognathus sp. A del Moral (2003)}

Figure 7I

2003 Amorphognathus sp. A. - del Moral, p. 279, pl. 1, fig. 5.

Description. - An ambalodiform element characterised by a large denticle in the posterior process.

Remarks. - Del Moral (2003) described a similar element from the Katian "unidad calcárea superior" of the Cantabrian Zone, yet with the basal margin nearly straight. The limited number of specimens recovered in our material inhibits making further inferences.

\section{Genus Sagittodontina Knüpfer, 1967}

Type species. - Sagittodontina robusta s.f. Knüpfer, 1967.

\section{Sagittodontina bifurcata Knüpfer, 1967}

Figures 7M, N, P-X; 8C, G, I

1997 Sagittodontina robusta Knüpfer. - Ferretti \& Barnes, pp. 30-32, pl. 4, figs 1-23.

1999 Sagittodontina robusta Knüpfer. - Sarmiento et al., pp. 495-496, pl. 1, figs 6-17, pl. 2, figs 1-5.

2008 Sagittodontina robusta Knüpfer. - del Moral \& Sarmiento, pp. 223-228, pl. 7, figs 1-21 (full synonymy).

2014a Sagittodontina robusta Knüpfer. - Ferretti et al., fig. $3 \mathrm{w}, \mathrm{z}-\mathrm{af}$.

Remarks. - We adopt here the original multielement designation of Bergström (1983) and Dzik (1989), based on the platform-equipped Pa element of Knüpfer (1967), and the apparatus reconstruction of del Moral \& Sarmiento (2008; Fig. 8G). The Sagittodontina specimens illustrated by Paris et al. (1981, pl. 2, figs 12,13), del Moral \& Sarmiento (2008), and Ferretti (1998, pl. 2, figs 1,2$)$ verify the symmetry of the $\mathrm{Pb}$ elements in the Sagittodontina apparatus. The pastinate elements ascribed to Sagittodontina (e.g. Dzik 1989, Fuchs 1990) may either represent a Pc element or, actually, belong to Noixodontus or a related genus. A few robust ramiform elements recovered are tentatively assigned to this species.

\section{"Sagittodontina" sp.}

Figures 8A, E, H; 9A-K

? 1992 Sagittodontina robusta Knüpfer. - Bergström \& Massa, pp. 1338-1339, pl. 1, figs 6-14.

Description. - Pa elements characterised by a long anterior process of relative uniform high, carrying $>8$ suberect denticles fused at its base. The anterior process is bar-like, aligned with the posterior process and softly curved; it is directed downwards at an angle of $c a .15^{\circ}$. The cusp is high and erect. The lateral process deflects downwards (mainly) and backwards from the anterior region of the cusp, producing a sort of anticusp, pointing outwards. The lateral process is short and may carry few denticles. In oral view, the $\mathrm{Pa}$ element gradually broadens from the anterior region to the posterior one. The posterior process lacks denticles close to the cusp and broadens posteriorly. The $\mathrm{Pb}$ element is scaphate, of triangular to crescent-shape in lateral view. It has a large basal sheath lateraly flattened, particularly on the anterior process. The latter carries seven-twelve proclined denticles. The outer lateral process develops as a bulge or adentate keeled margin from the anterior section of the cusp. In oral view, the posterior process is straight, lined with the cusp and the anterior process. It carries $>5$ denticles, though the more proximal are rudimentary. In complete specimens, an adentate posterolateral crease is observed running weakly from the inner posterior section of the cusp to a more defined edge in the basal sheath. The latter is more developed on the inner side of the $\mathrm{Pb}$ element, presenting a subsquared shape.

Remarks. - The posterior section of the Pa element illustrated as Sagittodontina robusta by Bergström \& Massa $(1992$, pl. 1, figs 13, 14) is similar to the type material (S. bifurcata s.f.) illustrated by Knüpfer (1967, pl. 7, fig. 5), but clearly different by its anterior bar (Fig. $8 \mathrm{C}, \mathrm{E})$. Therefore, it is possible that the Pa element in the apparatus reconstruction of Bergström \& Massa (1992) does not correspond with the type material from Thuringia, and then, would require a new formal designation. Moreover, the $\mathrm{Pb}$ element is possibly represented by Ambalodus triangularis indetantus Rhodes sensu Knüpfer (1967, pl. 9, fig. 1), which differs from Rhodes' type specimen (Rhodes, 1953, pl. 20, figs 35-37, 56) by the 


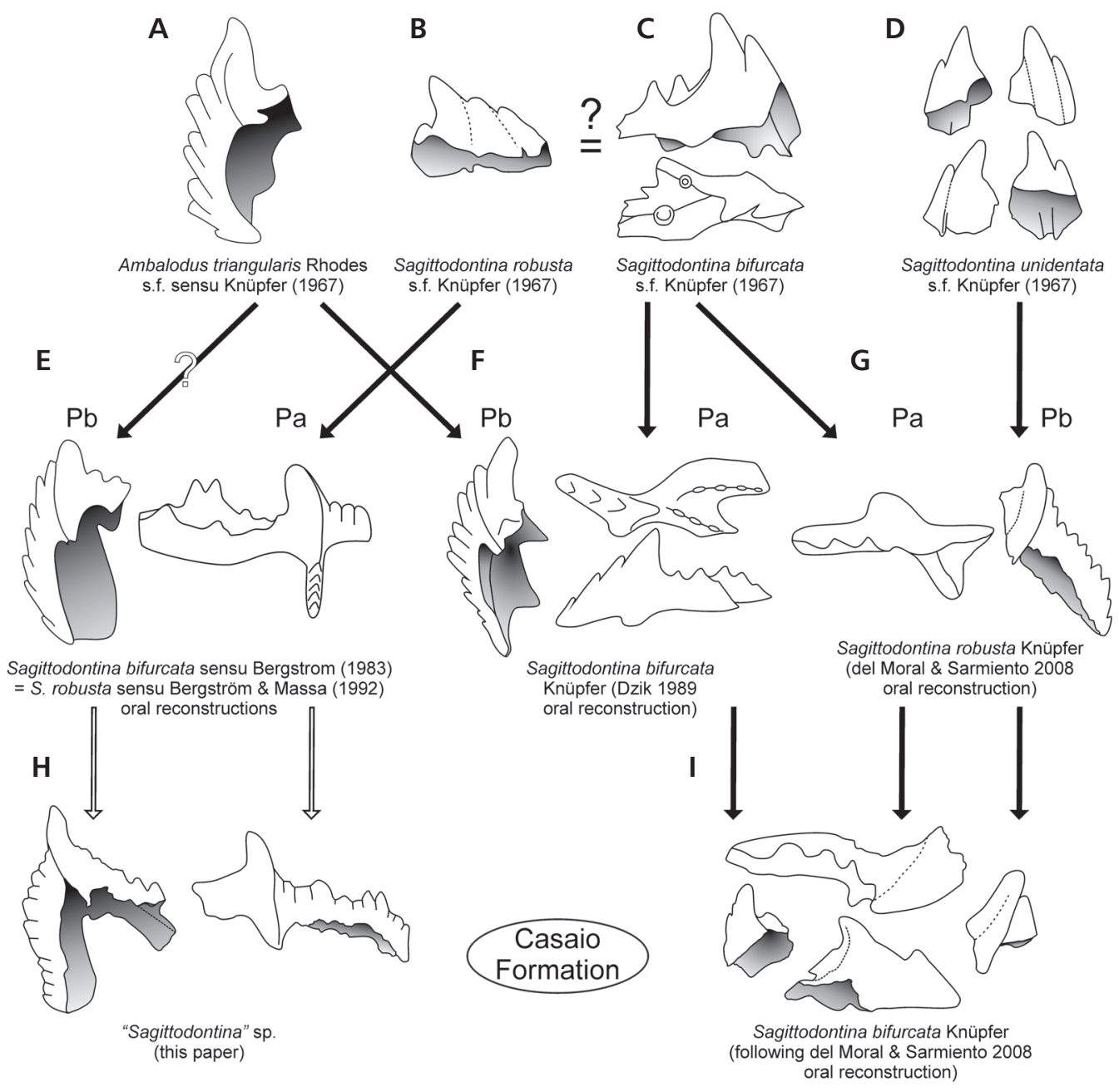

Figure 8. Proposed oral apparatus reconstructions for the genus Sagittodontina Knüpfer (1967), based on material originally described as form species from the Kalkbank Formation of Thuringia (A-D), and supported by studied collections from Libya (E), Thuringia (F), South Central Iberian Zone (G), and the conodont elements from the Casaio Formation, Northern Central Iberian Zone (H-I). The black arrows indicate how the form species of Knüpfer (1967) represent $\mathrm{Pa}$ or $\mathrm{Pb}$ elements in the alternative multielement hypothesis, not always supported by morphometrically comparable elements. The white arrows indicate the possible synonymy of S. bifurcata sensu Bergström (1983) with "Sagittodontina" sp. from the Casaio Formation.

thinner walls and the lack of basal ledge. Despite the absence of complete Pa elements in the Casaio Formation, its general shape suggests it is conspecific with the Libyan material.

Family Prioniodontidae Bassler, 1925

\section{Genus Baltoniodus Lindström, 1971}

Type species. - Prioniodus navis Lindström, 1954.

\section{?Baltoniodus sp. nov. A}

Figure 9L-Q, S-T

1967 Ambalodus triangularis triangularis Branson \& Mehl. - Knüpfer, p. 20, pl. 9, fig. 2a, b.
? 1985 Amorphognathus superbus Rhodes. - Bergström \& Orchard, p. 60, pl. 2.4, fig. 1 (only).

? 1990 Rhodesognathus elegans (Rhodes). - Fuchs, p. 206, pl. 6, figs 3, 4, pl. 7, fig. 5 .

1997 'ambalodiform' element. - Ferretti \& Barnes, pp. 36, 38, pl. 2, figs 11-13.

1999 Amorphognathus sp. - Sarmiento et al., p. 494, pl. 1, fig. 5.

2008 Amorphognathus aff. ordovicicus Branson \& Mehl. del Moral \& Sarmiento, p. 216, pl. 6, fig. 3 (only).

2008 Amorphognathus? sp. - Sarmiento et al., p. 88, pl. 2, fig. 5 (only).

Description. - Pa element pastinate, characterised by a long, straight and denticulated anterior bar. The cusp is stout and slightly proclined or reclined. The anterior 
outer lateral process deflects at $c a .45^{\circ}$ from the anterior edge of the cusp and progressively curves down and backwards. It is short and may carry small denticles. The posterior process is bar-like, rudimentary to denticulated. The angle between the anterior and posterior processes varies between $c a .75-125^{\circ}$. Only dextral Pa forms are known. $\mathrm{Pb}$ elements characterised by a long, generally curved anterior process with proclined denticles and by a posterior platform (rarely preserved), with anterolateral, posterior and posterolateral processes. The latter is delicately defined as a small sulcus in the basal cavity and in the oral surface by small, aligned denticles, diverging from approximately the first denticle of the posterior process.

Remarks. - $\mathrm{Pb}$ elements of ?Baltoniodus sp. nov. A are easily distinguished from their homologous elements in "Sagittodontina" sp. as the first possess a less flattened aspect and a less flaring basal sheath. P elements in ?Baltoniodus sp. nov. A may also resemble Rhodesognathus, though in the latter the anterolateral process branches from the first denticle anterior to the cusp and not as a rib from the anterior region of the cusp as it occurs in ?Baltoniodus sp. nov. A. In addition, the anterior basal ledge is apparently not conspicuous in all the specimens, as illustrated by Ferretti \& Barnes (1997, pl. 2, figs 11-13).

Family Icriodontidae Müller \& Müller, 1957

\section{Genus Icriodella Rhodes, 1953}

Type species. - Icriodella superba Rhodes, 1953.

Remarks. - Rhodes (1953) defined the genus Icriodella during the period of conodont form taxonomy, based on the characteristic platform $\mathrm{Pa}$ element with two rows of denticles on the anterior process (icrions). Bergström \& Sweet (1966) recognised a quinquimembrate apparatus of Icriodella, incorporating $\mathrm{Pb}$ (pyramidal pastinate), $\mathrm{M}$ (makellate) and $\mathrm{Sa}$ and $\mathrm{Sb}$ elements (alate and tertiopedate) to the oral reconstruction. Aldridge et al. (2013) described Notiodella keblon based on natural assemblages recovered from the Hirnantian Soom Shale of South Africa, recognising a 17-element apparatus. Aldridge et al. (2013) distinguished Notiodella from Icriodella based on the $\mathrm{M}$ element morphology, but leaving open its possible junior synonymy, which was later demonstrated by Bergström \& Ferretti (2014). Following the proposal of Dzik (2015), Icriodella consists of $2 \mathrm{P}_{1}(\mathrm{~Pa}), 2 \mathrm{P}_{2}(\mathrm{~Pb}), 2$ pairs of $\mathrm{M}, 1$ unpaired $\mathrm{S}\left(\mathrm{S}_{0}\right)$, and 8 paired $\mathrm{S}\left(\mathrm{S}_{1}-\mathrm{S}_{4}\right)$ elements.

\section{Icriodella iberiensis sp. nov.}

Figure 10A-I, K
1993 Icriodella superba Rhodes. - Sarmiento, p. 345-349, pl. 2, fig. 8, pl. 24, figs 1, 4, 5, 7, 8 .

1999 Icriodella sp. - Sarmiento et al., pp. 496, 497, pl. 2, figs 12,15 .

2007 Icriodella superba Rhodes. - del Moral, pp. 225-227, pl. 5, fig. 1, pl. 33, figs $1-17$.

2008 Icriodella superba Rhodes. - del Moral \& Sarmiento, pp. 230-232, pl. 8, figs 1-15.

2014b Icriodella superba Rhodes. - Ferretti et al., fig. 13u-v.

2016 Icriodella superba Rhodes. - Mavrinskaya \& Yakupov, pl. 1, fig. 15.

Types. - Holotype: $\mathrm{P}_{1}$ element MGM-8209O-43 (Fig. 10B), Paratypes: $\mathrm{P}_{1}$ elements MGM-8209O-42 (Fig. 10A), MGM-8209O-44 (Fig. 10C), MGM-8209O-45 (Fig. 10D), MGM-8209O-47 (Fig. 10F). Sample CA2.2, Trigal limestones, Casaio Formation.

Etymology. - After the Iberian Massif, from where it is defined.

Diagnosis. - A species of lcriodella in which the $\mathrm{P}_{1}$ element is characterized by a short posterior process, measuring $c a$. 1:5 or less of the length of the anterior process. The posterior process may carry up to four rudimentary denticles, whereas the elongated anterior process carries up 12 discrete denticles distributed along two rows, generally aligned in pairs. The basal cavity is deep and occupies the entire length of the element.

Description. - The $\mathrm{P}_{1}$ element is narrow, pastiniscaphate, with a long anterior process and short lateral and posterior processes. The longer process is broad and tapers gradually anteriorward. It may bear up to 12 denticles; these may present different arrangements but characteristically occur in pairs aligned perpendicular to each lateral margin. Unpaired, centred denticles are common towards the narrow anterior extremity of the $\mathrm{P}_{1}$ element. A single denticle may also occur at approximately halfway between the cusp and the paired-rows of denticles. Centreddenticles may appear in other parts of the anterior process but are less frequent. The cusp is double the anterior denticles in height. It is reclined, laterally compressed, and presents a well-developed external lateral costa that projects into a process, but rarely preserved. The posterior process is short and bears up to four short, basally-fused denticles, the uppermost is located at $c a$. mid-height of the cusp. Basal cavity is well developed along the entire length of the element. The $\mathrm{P}_{2}$ element is pyramidal pastinate, defined by anterior, posterior and anterolateral basal processes. The inner flank is flat whereas the outer and the anterior flanks are slightly concave. The angle between the anterior and the posterior margins ranges from $20-40^{\circ}$, defining a deep basal cavity. Cusp height is extremely 


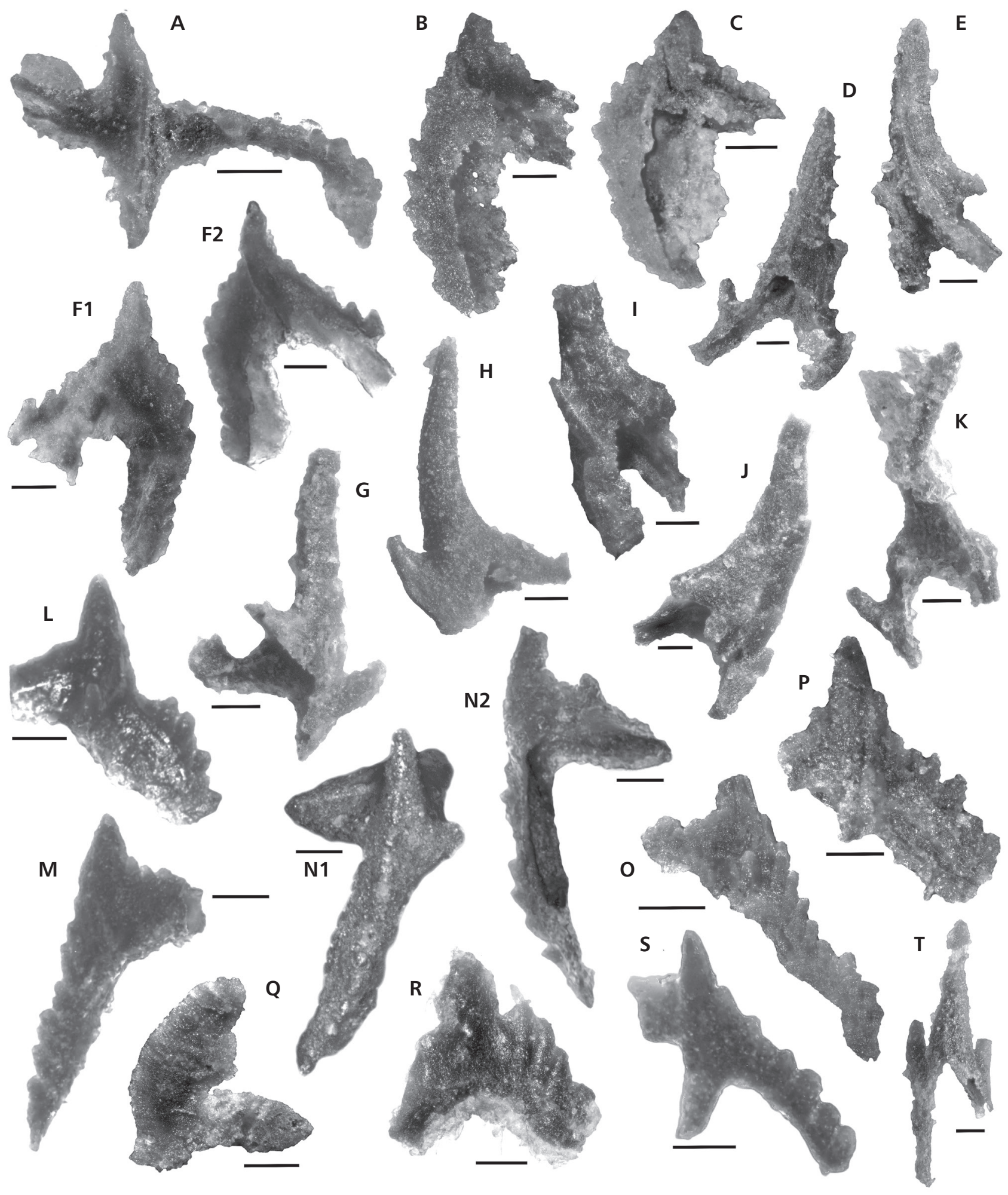

Figure 9. Late Katian conodonts from the Trigal limestones of the Casaio Formation, northern Central Iberian Zone. The elements $\mathrm{C}$ and $\mathrm{Q}$ are from sample CA2, the remainder from sample CA2.2. • A-K - "Sagittodontina" sp.; A - Pa element, MGM-8209O-24; B - Pb element, MGM-8209O-25; C - Pb element, MGM-8208O-2; D - Sa element, MGM-8209O-26; E - Sa element, MGM-8209O-27; F - Pb element, MGM-8209O-28; G - Sb element, MGM-8209O-29; H - Sc element, MGM-8209O-30; I - Sd element, MGM-8209O-31; J - Sd element, MGM-8209O-32; K - Sb element, MGM-8209O-33. • L-Q, S, T - ?Baltoniodus sp. nov. A; L - Pa element, MGM-8209O-34; M - Pb element, MGM-8209O-35; N - Pb element, MGM8209O-36; O - Pa element, MGM-8209O-37; P - Pa element, MGM-8209O-38; Q - ?M element, MGM-8208O-3; S - Pa element, MGM-8209O-39; $\mathrm{T}-$ ?Sa element, MGM-8209O-40. $\bullet \mathrm{R}$ - Eocarniodus aff. gracilis (Rhodes), ?Sb element, MGM-8209O-41. All scale bars are $100 \mu \mathrm{m}$. 
variable. The $\mathrm{M}$ elements are subtriangular in lateral and oral views, producing three slightly concave walls. Cusp is proclined and relatively short. Long anterior process carrying short, proclined denticles. No denticulation is discernible on posterior or outer-lateral process. Basal cavity deep, which extends under whole element. The $\mathrm{S}$ elements recovered closely resemble the $\mathrm{P}_{2}$ element. They are tertiopedate, laterally compressed, triangular in lateral view, adenticulate, and have a relatively short cusp. The lateral costa runs mid-way between the anterior and posterior processes.

Remarks. $-\mathrm{P}_{1}$ elements of Icriodella iberiensis sp. nov. are clearly discernible from typical populations of I. superba by the unequal length of the processes (Orchard 1980). The $\mathrm{P}_{1}$ element of $I$. prominens Orchard differs mainly from its homologous element in I. iberiensis by its larger cusp, more developed posterior process, and in the outline of the anterior process as seen in oral view. The $\mathrm{P}_{1}$ element of Icriodella sp. nov. A (Nowlan 1983) from the Grog Brook Group, New Brunswick, also presents a short posterior process, yet the denticulation on the anterior margin is rudimentary or absent and replaced by transverse ridges. Furthermore, the $\mathrm{P}_{1}$ element of $I$. iberiensis sp. nov. differs conspicuously from the $\mathrm{P}_{1}$ element of I. rhodesi Bergström \& Ferretti (2014) in the height of the cusp and in the style of denticulation of the anterior process, characterised by transversal ridges. Savage \& Bassett (1985) illustrated as I. superba a $\mathrm{P}_{1}$ element with a short posterior process (pl. 82, fig. 30) that resembles I. iberiensis sp. nov.; however, the former has small transverse ridges connecting the anterior denticles, and the aboral margin is situated higher at the posterior bar.

Microstructure: Sarmiento (1993) described a delicate striation in the $\mathrm{P}_{2}$ elements recovered from the Urbana Limestone, later verified by del Moral (2007), and confirmed also in our specimens.

Order Belodellida Sweet, 1988

Family Ansellidae Fåhræus \& Hunter, 1985

\section{Genus Hamarodus Viira, 1974}

Type species. - Distomodus europaeus Serpagli, 1967.

\section{Hamarodus brevirameus (Walliser, 1964)}

Figure 10J, L-O

1964 ?Neoprioniodus brevirameus n. sp.; Walliser, p. 47, pl. 4, fig. 5, pl. 29, figs 5-10 (Sc element).

1967 Distomodus europaeus n. sp.; Serpagli, p. 64, pl. 14, figs 1-6 (P element).

1994 Hamarodus brevirameus (Walliser). - Dzik, p. 111, pl. 24, figs 14-19, text-fig. 31a.
1998 Hamarodus europaeus (Serpagli). - Ferretti \& Serpagli, pp. 226-228, pl. 2, figs 1-14.

2008 Hamarodus europaeus (Serpagli). - del Moral \& Sarmiento et al., pp. 184-188, pl. 1, figs 3-22, pl. 2, figs 1-3 (full synonymy).

2014b Hamarodus brevirameus (Walliser). - Ferretti et al., fig. 13a-c, e-g, i, j.

2014 Hamarodus brevirameus (Walliser). - Bergström \& Ferretti, fig. 11a-h.

Remarks. - Dzik (1994) considered Hamarodus europaeus as junior subjective synonym of $H$. brevirameus (Walliser) after reassessing the ramiform elements found by Walliser (1964) in the Cellon Section in the Carnic Alps. According to del Moral (2007), the differences between the Pa and $\mathrm{Pb}$ elements (e.g. Dzik 1989, Orchard 1980) are subtle and do not justify its differentiation. Del Moral (2007) provided a detailed description of the components of the apparatus of Hamarodus europaeus, which contains P, M, $\mathrm{Sa}, \mathrm{Sb}, \mathrm{Sc}$, and $\mathrm{Sd}$ elements.

Order Panderodontida Sweet, 1988

Family Panderodontidae Lindström, 1970

\section{Genus Panderodus Ethington, 1959}

Type species. - Paltodus unicostatus Branson \& Mehl, 1933.

Panderodus gracilis (Branson \& Mehl, 1933)

Figure 10P, Q

1933 Paltodus gracilis; Branson \& Mehl, p. 108, pl. 8, figs 20, 21.

1995 Panderodus gracilis (Branson \& Mehl). - Trotter \& Webby, p. 483, pl. 5, figs 1-4, 9, 10, 12-15.

2008 Panderodus gracilis (Branson \& Mehl). - del Moral \& Sarmiento, pp. 200, 202-204, pl. 4, figs 1-11 (full synonymy).

Remarks. - A symmetrical coniform element with a lateral costa on each side, fine striations and bifurrowed was recovered from the Casaio Formation, with both anterior and posterior margins rounded. A second element, despite being slightly deformed, is characterised by a proclined cusp, striae, and two weakly developed panderontid sulcus asymmetrically located, and rounded anterior and keeled posterior margins. The first element would correspond to the aequaliform element, and the second one to the graciliform element, according to the descriptive terminology of Sansom et al. (1994).

Panderodus panderi (Stauffer, 1940)

Figure 10V 


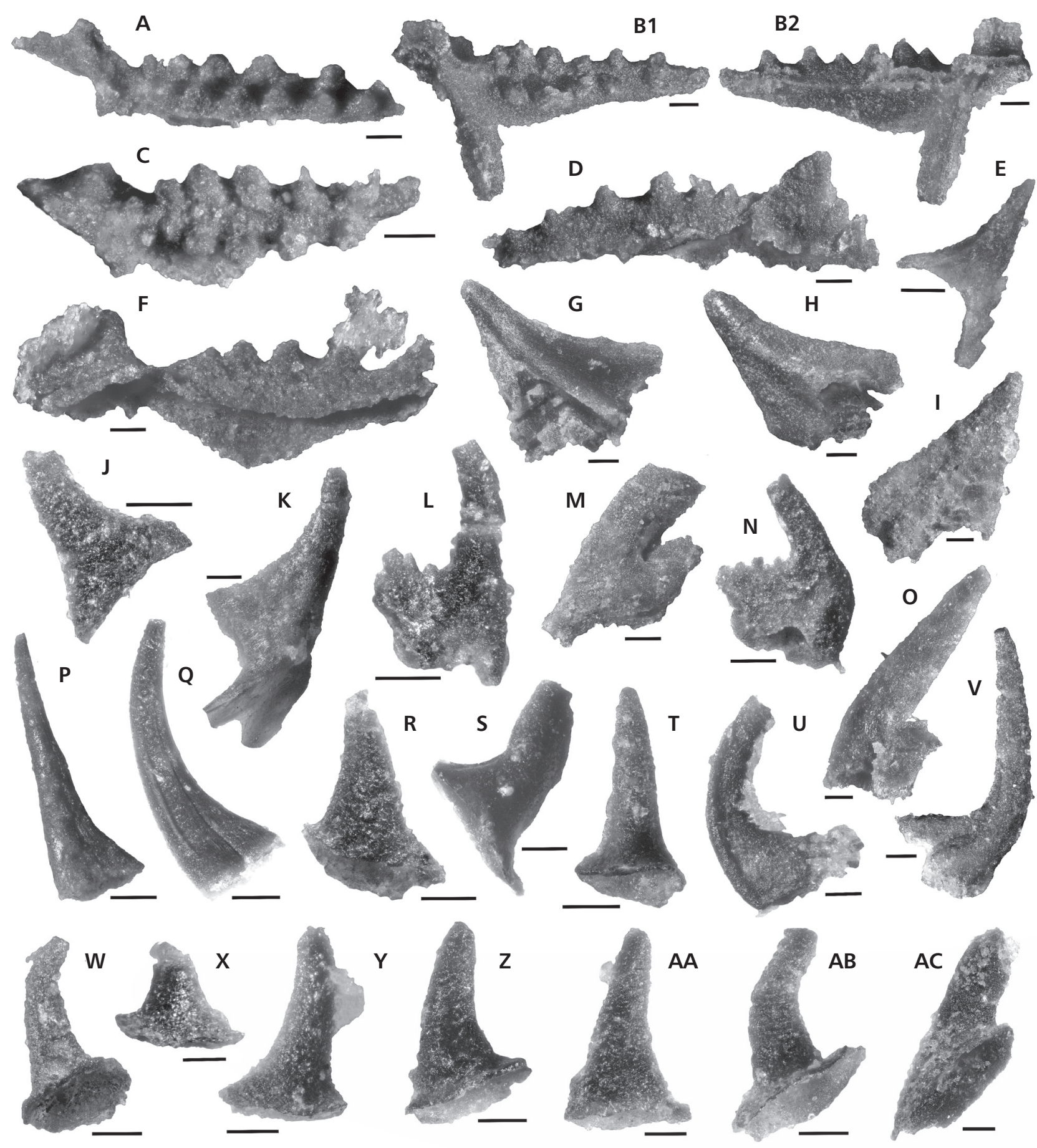

Figure 10. Late Katian conodonts from the Trigal limestones of the Casaio Formation, northern Central Iberian Zone. The elements $\mathrm{G}$ and $\mathrm{O}$ are from sample CA2, the remainder from sample CA2.2. • A-I, K - Icriodella iberiensis sp. nov.; A - $\mathrm{P}_{1}$ element, MGM-8209O-42 (paratype); $\mathrm{B}-\mathrm{P}_{1}$ element, MGM-8209O-43 (holotype); C - $\mathrm{P}_{1}$ element, MGM-8209O-44 (paratype); D - $\mathrm{P}_{1}$ element, MGM-8209O-45 (paratype); E - M element, MGM-8209O-46; F - $\mathrm{P}_{1}$ element, MGM-8209O-47 (paratype); G - $\mathrm{P}_{2}$ element, MGM-8208O-4; H - $\mathrm{P}_{2}$ element, MGM-8209O-48; I - S element, MGM-8209O-49; K - $\mathrm{P}_{2}$ element, MGM-8209O-50. • J, L-O - Hamarodus brevirameus (Walliser); J - P element, MGM-8209O-51; L - Sc element, MGM-8209O-52; M - M element, MGM-8209O-53; N - Sc element, MGM-8209O-54; O - M element, MGM-8208O-5. • P, Q - Panderodus gracilis (Branson \& Mehl); P - graciliform element, MGM-8209O-55; Q -aequaliform element, MGM-8209O-56. • R, S, U - Drepanoistodus cf. suberectus (Branson \& Mehl); R - Sa element, MGM-8209O-57; S - P element, MGM-8209O-58; U - S element, MGM-8209O-59. • T - "Drepanodus suberectus" (Branson \& Mehl) sensu Rexroad, 1967 s.f., MGM-8209O-60. • V - Panderodus panderi (Stauffer), MGM-8209O-61. • W-AC - ?Drepanoistodus sp.; W - S element, MGM-8209O-62; X - ?Sa element, MGM-8209O-63; Y - S element, MGM-8209O-64; Z - S element, MGM-8209O-65; AA - S element, MGM-8209O-66; AB - S element, MGM-8209O-67; AC - M element, MGM-8209O-68. All scale bars are $100 \mu \mathrm{m}$. 
1940 Paltodus panderi; Stauffer, p. 427, pl. 60, figs 8, 9.

1979 Panderodus panderi (Stauffer). - Sweet, p. 64, fig. 7.2-7.6, 7.10.

1981 Panderodus panderi (Stauffer). - Nowlan \& Barnes, p. 17, pl. 6, figs 3-4, 14.

?2008 Panderodus panderi? (Stauffer). - del Moral \& Sarmiento, pp. 205, 206, pl. 2, figs 12, 13 (full synonymy).

Remarks. - The recovered element is characterised by an erect cusp, short base, a weakly defined sulcus proximate to the inner anterior margin, and the panderodontid sulcus located in a median position on the outer face of the element. The strong curvature of the element, the basal thickening, and the posterior extension of the base is consistent with previous reports for this species.

Order Protopanderodontida Sweet, 1988

Family Drepanoistodontidae Bergström, 1981

\section{Genus Drepanoistodus Lindström, 1971}

Type species. - Oistodus forceps Lindström, 1954.

\section{?Drepanoistodus sp.}

Figure $10 \mathrm{~W}-\mathrm{AC}$

1997 Drepanoistodus? sp. - Ferretti \& Barnes, p. 33, pl. 5, figs $1-12$.

Description. - Simple cone, erect to slightly recurved with a large basal cross-section. Elements laterally compressed with weakly keeled anterior and posterior margins, and deep basal cavity. A rudimentary denticle or protuberance may occur low on the anterior margin. Oistodiform (M) element laterally compressed with a wide base and slightly geniculated.

Remarks. - The few elements recovered are consistent with the illustrated specimens from Thuringia (Ferretti \& Barnes 1997), but do not allow reconstruction of its apparatus.

Family Protopanderodontidae Lindström, 1970

\section{Genus Scabbardella Orchard, 1980}

Type species. - Drepanodus altipes Henningsmoen, 1948.

\section{Scabbardella altipes (Henningsmoen, 1948)}

Figure 11A-F

1948 Drepanodus altipes n. sp.; Henningsmoen, p. 420, pl. 25, fig. 14 .
1980 Scabbardella altipes (Henningsmoen). - Orchard, pp. 25, 26, pl. 5, figs 2-5, 7-8, 12, 14, 18, 20, 23, 24, 28, $30,33,35$, text-fig. $4 \mathrm{c}$ (multielement taxonomy).

2008 Scabbardella altipes (Henningsmoen). - del Moral \& Sarmiento, pp. 189-192, pl. 3 , fig. 1-20.

2010 Scabbardella altipes (Henningsmoen). - RodríguezCañero et al., fig. 5.9-5.12.

2015 Scabbardella altipes (Henningsmoen). - Zhen et al., pp. 111-115, figs 13-15 (full synonymy).

2018 Scabbardella altipes (Henningsmoen). - Zhang et al., fig. $3 \mathrm{k}-\mathrm{m}$.

Remarks. - Orchard (1980) recognised a seximembrate apparatus in Scabbardella composed of two drepanodiforms, two acodiforms and two distacodiforms elements, arranged in a symmetry transition series. Based on a large collection from the Wairuna Formation (middle Katian) of North Queensland, Zhen et al. (2015) distinguished longbased (M1) and short-based (M2) drepanodiform elements with smooth lateral faces, long-based symmetrical (Sa) and short-based slightly asymmetrical (Sd) distacodiform elements with a broad carina or prominent costa adjacent to a deep and narrow groove on each lateral side, and longbased $(\mathrm{Sb})$ and short-based $(\mathrm{Sc})$ acodiform elements with a deep and narrow groove on the external flank.

It is noteworthy that despite the pervasive cleavage that affects the specimens, fine longitudinal striations of S. altipes are still visible (Fig. 11B). This character helps to distinguish it from Besselodus and Dapsilodus, which are characterised by oblique fine striations on the anterior basal margin.

Order unknown

Family unknown

"Drepanodus suberectus" (Branson \& Mehl) sensu Rexroad (1967) s.f.

Figure 10T

1967 Drepanodus suberectus (Branson \& Mehl). - Rexroad, pp. 30, 31, pl. 2, fig. 4.

1981 "Drepanodus suberectus" (Branson \& Mehl) (sensu Rexroad) s.f. - McCracken \& Barnes, p. 76, pl. 7, fig. 43.

1986 Noixodontus girardeauensis (Satterfield). - Amsden \& Barrick, p. 68, pl. 7, fig. 8 (only).

Remarks. - As it was observed by McCracken \& Barnes (1981) in the Ellis Bay Formation, simple cones from Silurian strata have been incorrectly referred to as D. suberectus s.f. because those elements are anteroposteriorly compressed rather than laterally compressed. Similar elements along with others corresponding to Istorinus erectus were interpreted by Amsden \& Barrick (1986) as the morphotype A of Noixodontus. The single 


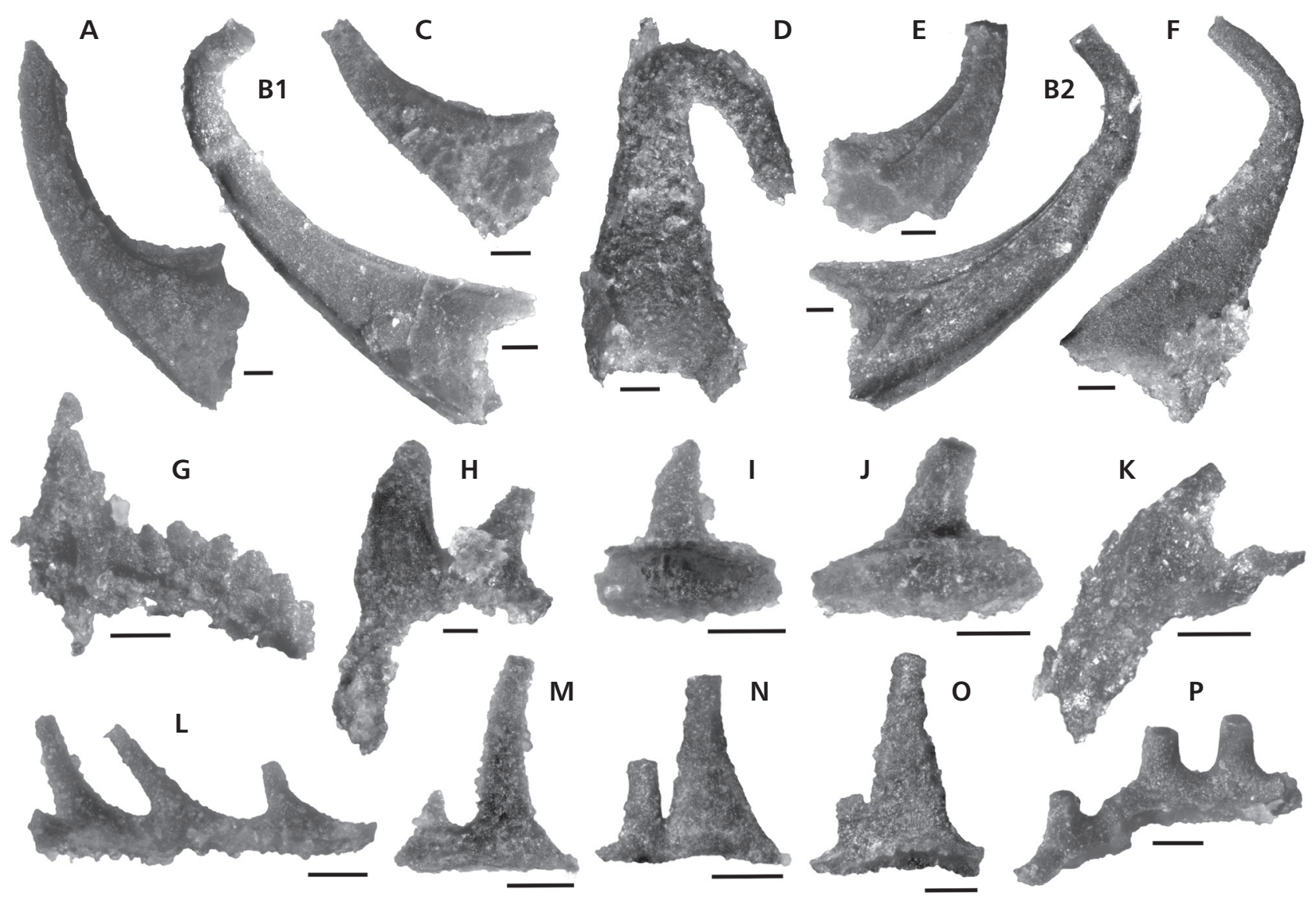

Figure 11. Late Katian conodonts from the Trigal limestones of the Casaio Formation, northern Central Iberian Zone. The elements B, C, G, $\mathrm{K}$ and $\mathrm{P}$ are from sample CA2, the remainder from sample CA2.2. $-\mathrm{A}-\mathrm{F}-$ Scabbardella altipes (Henningsmoen); A - acodiform, MGM-8209O-69; B - distacodiform, MGM-8208O-6; C- acodiform, MGM-8208O-7; D - distacodiform, MGM-8209O-70; E - acodiform, MGM-8209O-71; F - drepanodiform, MGM-8209O-72. • G-H, K - indeterminate conodont elements; G - MGM-8208O-8; H - MGM-8209O-73; K - MGM-8208O-9. • L - ramiform fragment, MGM-8209O-74. • I, J - “Clavohamulus sp. 1" Knüpfer; I - MGM-8209O-75; J - MGM-8209O-76. • M-O - Istorinus erectus Knüpfer; M - MGM-8209O-77; N - MGM-8209O-78; O - MGM-8209O-79. • P - gen. et sp. indet. A, MGM-8208O-10.

element recovered from the Casaio Formation does not allow to make further inferences.

\section{Genus Eocarniodus Orchard, 1980}

Type species. - Prioniodus gracilis Rhodes, 1955.

\section{Eocarniodus aff. gracilis (Rhodes, 1955)}

Figure 9R

2014b Eocarniodus aff. E. gracilis (Rhodes). - Ferretti et al., p. 825 , fig. 10 , fig. 16b-d, f-p, r-v (full synonymy).

Remarks. - A minute, robust element with thickened lateral margins was recovered from sample CA2. It is aborally deflected, probably an original character increased by deformation. It has anterior and posterior processes carrying basally fused denticles. Its general aspect corresponds to the $\mathrm{Sb}$ ? elements of Eocarniodus illustrated by Ferretti et al. (2014b).

\section{Genus Istorinus Knüpfer, 1967}

Type species. - Istorinus erectus Knüpfer, 1967.

\section{Istorinus erectus Knüpfer, 1967}

Figure $11 \mathrm{M}-\mathrm{O}$

1967 Istorinus erectus n. sp.; Knüpfer, p. 31, pl. 6, figs 4-6.

? 2000 Istorinus? sp. - Furey-Greig, p. 138, fig. 5.16.

2008 Istorinus erectus Knüpfer. - del Moral \& Sarmiento, p. 233, pl. 2, figs 21-23.

2014a Istorinus erectus Knüpfer. - Ferretti et al., fig. 31.

2014b Istorinus erectus Knüpfer. - Ferretti et al., fig. 16a-e.

? 2014b Eocarniodus aff. E. gracilis (Rhodes). - Ferretti et al., fig. 16k, 1 . 
Remarks. - Following the descriptive classification of Ferretti \& Barnes (1997), only the morphotype 2 of Istorinus erectus is present in the Casaio Formation, i.e. conodonts with triangular shape, straight base and anteroposteriorly compressed. A secondary denticle may emerge from the cusp itself or being discrete, small or up to half cusp height.

\section{Gen. et sp. indet. A}

Figure 11P

Remarks. - A single curved bar fragment with three widely spaced, suberect peg-like denticles was recovered. The basal cavity is well defined along the entire length of the fragment, distally reducing in size. By the characteristics of the fragment, it probably represents another conodont genus (e.g. ?Oulodus, ?Plectodina) in the Casaio Formation.

\section{Conclusions}

A reassessment of the conodont faunas of the Casaio Formation from the northern Central Iberian Zone not only confirms a late Katian Amorphognathus ordovicicus Zone depositional time for its meta-limestones, but confirms as well that the Katian conodont taxonomy and biostratigraphy is far from being stabilised, and that more studies for the refinement of the long-ranging Amorphognathus ordovicicus Zone and its faunas are required. In that sense, the different species of Icriodella, such as I. iberiensis sp. nov., which have wide palaeogeographic distribution, may provide additional tools to improve biostratigraphic resolution and regional correlations. Additionally, our taxonomic study notes the variety of elements that have been attributed to Sagittodontina, but which are difficult to reconcile with previous oral reconstructions, probably reflecting mixed generic assignments. Finally, the conodont faunas from the Casaio Formation provided additional clues on the timing and nature of the first pulse of Katian limestone deposition (Boda Event) in NW Spain.

\section{Acknowledgements}

Senior author greatly thanks CONICET and the Geology Department of the Oviedo University for a visiting research fellowship. Particular thanks are extended to C. Aramburu, F. Bastida, and L.P. Fernández for introducing him to the geology of Spain. J.L. Alonso and S. García-López provided insightful discussions and continuous support. We appreciate useful comments by the reviewers of the manuscript, A. Ferretti and P. Männik. We are indebted to C.R. Barnes, who provided extensive suggestions to improve this manuscript. This is a contribution to the IGCP 653 , The onset of the Great Ordovician Biodiversification Event.

\section{References}

Aldridge, R.J. \& JePPSSOn, L. 1984. Ecological specialists among Silurian conodonts. Palaeontology 32, 141-149.

Aldridge, R.J., Murdock, D.J.E., Gabbott, S.E. \& Theron, J.N. 2013. A 17-element conodont apparatus from the Soom Shale Lagerstätte (Upper Ordovician), South Africa. Palaeontology 56(2), 261-276. DOI 10.1111/j.1475-4983.2012.01194.x

Aldridge, R.J., Purnell, R.J., Gabbott, S.E. \& Theron, J.N. 1995. The apparatus architecture and function of Promissum pulchrum Kovács-Endrödy (Conodonta, Upper Ordovician) and the prioniodontid plan. Philosophical Transactions of the Royal Society of London. Series B: Biological Sciences 347(1321), 275-291. DOI 10.1098/rstb.1995.0027

Amsden, T.W. \& Barrick, J.E. 1986. Late Ordovician-Early Silurian strata in the Central United States and the Hirnantian Stage. Oklahoma Geological Survey Bulletin 139, 1-103.

Aramburu, C., Méndez-Bedia, I. \& Arbizu, M. 2002. The Lower Palaeozoic in the Cantabrian Zone (Cantabrian Mountains, NW Spain), 35-49. In García-López, S. \& Bastida F. (eds) Palaeozoic Conodonts from Northern Spain. Cuadernos del Museo Geominero 1. Instituto Geológico y Minero de España, Madrid.

Bagnoli, G., Ferretti, A., Serpagli, E. \& Vai, G.B. 1988. Late Ordovician conodonts from the Valbertad Section (Carnic Alps). Giornale di Geologia 60, 138-149.

BARNES, C.R. 2019. Impacts of climate-ocean-tectonic changes on early Paleozoic conodont ecology and evolution evidenced by the Canadian part of Laurentia. Palaeogeography, Palaeoclimatology, Palaeoecology.

DOI 10.1016/j.palaeo.2019.02.018

BARNES, C.R. \& FÅHRÆUS, L.E. 1975. Province, communities, and the proposed nektobenthic habit of Ordovician conodontophorids. Lethaia 8, 133-149.

DOI 10.1111/j.1502-3931.1975.tb01308.x

Barros Lorenzo, L.C. 1989. Nuevos datos geológicos y cartográficos sobre el flanco Sur del Sinclinorio de Truchas (Ourense-León, NW de España). Cuadernos do Laboratorio Xeolóxico de Laxe 14, 93-116.

Bartlett, R., Elrick, M., Wheeley, J.R., Polyak, V., Desrochers, A. \& Asmerom, Y. 2018. Abrupt global-ocean anoxia during the Late Ordovician-early Silurian detected using uranium isotopes of marine carbonates. Proceedings of the National Academy of Sciences 115(23), 5896-5901. DOI 10.1073/pnas.1802438115

BAsSLER, R.S. 1925. Classification and stratigraphic use of the conodonts. Geological Society of America Bulletin 36, 218 220.

Bateson, W. 1886. The ancestry of the Chordata. Quarterly Journal of Microscopical Science 26, 535-571.

Bergström, S.M. 1981. Drepanoistodontidae, 128-129. In Robison, R.A. (ed.) Treatise on Invertebrate Paleontology, 
Part W, Miscellanea (Supplement 2) Conodonta. Geological Society of America, Boulder, Colorado.

Bergström, S.M. 1983. Biogeography, evolutionary relationships, and biostratigraphic significance of Ordovician platform conodonts. Fossils and Strata 15, 35-58.

Bergström, S.M. \& Ferretti, A. 2014. Conodonts in the Upper Ordovician Keisley Limestone of northern England: taxonomy, biostratigraphical significance and biogeographical relationships. Papers in Palaeontology 1(1), 1-32.

DOI 10.1002/spp2.1003

Bergström, S.M. \& Leslie, S.A. 2010. The Ordovician zone index conodont Amorphognathus ordovicicus Branson \& Mehl, 1933 from its type locality and the evolution of the genus Amorphognathus Branson \& Mehl, 1933. Journal of Micropalaeontology 29(1), 73-80. DOI 10.1144/jm.29.1.73

Bergström, S.M. \& Massa, D. 1992. Stratigraphic and biogeographic significance of Upper Ordovician conodonts from northwestern Libya, 1323-1342. In SALEM, M.J., Hammuda, O.S. \& Eliagoubi, B.A. (eds) The Geology of Libya. Elsevier, Amsterdam.

Bergström, S.M. \& Orchard, M.J. 1985. Conodonts of the Cambrian and Ordovician Systems from the British Isles, 32-67. In Higgins, A.C. \& Austin, R.L. (eds) A stratigraphical index of conodonts. Ellis Horwood Limited.

Bergström, S.M. \& Sweet, W.C. 1966. Conodonts from the Lexington Limestone (Middle Ordovician) of Kentucky and its equivalents in Ohio and Indiana. Bulletins of American Paleontology 50(229), 271-441.

Bergström, S.M., Xu, C., Gutiérrez-Marco, J.C. \& Dronov, A. 2009. The new chronostratigraphic classification of the Ordovician System and its relations to major regional series and stages and to $\delta 13 \mathrm{C}$ chemostratigraphy. Lethaia $42(1)$, 97-107. DOI 10.1111/j.1502-3931.2008.00136.x

Boucot, A.J, Jia-Yu, R., Xu, C. \& Scotese, C.R. 2003. Pre-Hirnantian Ashgill climatically warm event in the Mediterranean region. Lethaia 36(2), 119-131.

DOI 10.1080/00241160310001245

Branson, E.B. \& Branson, C.C. 1947. Lower Silurian conodonts from Kentucky. Journal of Paleontology 21, 549-556.

Branson, E.B. \& Mehl, M.G. 1933. Conodonts studies n 2: Conodonts from the Joachim (Middle Ordovician) of Missouri; Conodonts from the Plattin (Middle Ordovician) of Missouri; Conodonts from the Maquoketa-Thebes (Upper Ordovician) of Missouri; A study of Hinde's types of conodonts preserved in the British Museum. University of Missouri Studies 8(2), 77-167.

CARls, P. 1975. The Ordovician of the Eastern Iberian Chains near Fombuena and Luesma (Prov. Zaragoza, Spain). Neues Jahrbuch für Geologie und Paläontologie Abhandlungen 150(2), 127-146.

Cherns, L. \& Wheeley, J.R. 2007. A pre-Hirnantian (Late Ordovician) interval of global cooling - The Boda event re-assessed. Palaeogeography, Palaeoclimatology, Palaeoecology 251(3), 449-460. DOI 10.1016/j.palaeo.2007.04.010

Cooper, B.J. 1975. Multielemental conodonts from the Brassfield Limestone (Silurian) of Southern Ohio. Journal of Paleontology 49(6), 984-1008.
Cooper, R.A., Sadler, P.M., Hammer, O. \& Gradstein, F.M. 2012. Chapter 20 - The Ordovician Period, 489-523. In Gradstein, F.M., OGg, J.G., Schmitz, M.D. \& OGG, G.M. (eds) The Geologic Time Scale. Elsevier, Boston.

DOI 10.1016/B978-0-444-59425-9.00020-2

Del Moral, B. 2003. Primeros conodontos kralodvorienses (Ordovícico Superior) de la Zona Cantábrica, Portilla de Luna, León (España). Revista Española de Micropaleontología 35(3), 275-283.

Del Moral, B. 2007. Conodontos y microfacies del Ordovícico Superior de la Cordillera Ibérica y Sierra Morena oriental. 427 pp. Ph.D. thesis, Universidad Complutense de Madrid, Spain.

del Moral, B. \& Sarmiento, G.N. 2008. Conodontos del Katiense (Ordovícico Superior) del sector meridional de la Zona Centroibérica (España). Revista Española de Micropaleontología 40(3), 169-245.

DzIK, J. 1976. Remarks on the evolution of the Ordovician conodonts. Acta Palaeontologica Polonica 21, 395-455.

DzIK, J. 1989. Conodont evolution in high latitudes of the Ordovician. Courier Forschungsinstitut Senckenberg 117, $1-28$.

Dzik, J. 1994. Conodonts of the Mójcza Limestone. Acta Palaeontologica Polonica 53, 43-128.

DzIK, J. 1998. Evolution of the Late Ordovician high-latitude conodonts and dating of Gondwana glaciations. Bolletino della Società Paleontologica Italiana 37(2-3), 237-253.

Dzik, J. 2015. Evolutionary roots of the conodonts with increased number of elements in the apparatus. Earth and Environmental Science Transactions of the Royal Society of Edinburgh 106(1), 29-53. DOI 10.1017/S1755691015000195

Eichenberg, W. 1930. Conodonten aus dem Culm des Harzes. Paläontologische Zeitschrift 12, 177-182. DOI 10.1007/BF03044446

Epstein, A.G., Epstein, J.B. \& Harris, L.D. 1977. Conodont color alteration - An index to organic metamorphism. Geological Survey Professional Paper 995, 1-27. DOI 10.3133/pp995

Ethington, R.L. 1959. Conodonts of the Ordovician Galena Formation. Journal of Paleontology 33(2), 257-292.

FÅnræus, L.E. \& Hunter, D.R. 1985. Simple-cone conodont taxa from the Cobbs Arm Limestone (Middle Ordovician), New World Island, Newfoundland. Canadian Journal of Earth Sciences 22(2), 1171-1182. DOI 10.1139/e85-120

Ferretti, A. 1998. Late Ordovician conodonts from the Prague Basin, Bohemia. Palaeontologia Polonica 58, 123-139.

Ferretti, A. \& Barnes, C.R. 1997. Upper Ordovician conodonts from the Kalkbank limestone of Thuringia, Germany. Palaeontology 40, 15-42.

Ferretti , A. \& Schönlaub, H.P. 2001. New conodont faunas from the Late Ordovician of the Central Carnic Alps, Austria. Bollettino della Società Paleontologica Italiana 40, 3-15.

Ferretti, A. \& Serpagli, E. 1991. First record of Ordovician conodonts from southwestern Sardinia. Rivista Italiana di Paleontologia e Stratigrafia 97(1), 27-34.

Ferretti, A. \& Serpagli, E. 1998. Late Ordovician conodont faunas from southern Sardinia, Italy: biostratigraphic 
and paleogeographic implications. Bolletino della Società Paleontologica Italiana 37(2-3), 215-236.

Ferretti, A., Bergström, S.M. \& Barnes, C.R. 2014b. Katian (Upper Ordovician) conodonts from Wales. Palaeontology 57(4), 801-831. DOI 10.1111/pala.12089

Ferretti, A., Bergström, S.M. \& Sevastopulo, G.D. $2014 \mathrm{c}$. Katian conodonts from the Portrane Limestone: the first Ordovician conodont fauna described from Ireland. Bollettino della Società Paleontologica Italiana 53(2), 105-119.

Ferretti, A., Messori, A. \& Bergström, S.M. 2014a. Composition and significance of the Katian (Upper Ordovician) conodont fauna of the Vaux Limestone ('Calcaire des Vaux') in Normandy, France. Estonian Journal of Earth Sciences 63(4), 214-219. DOI 10.3176/earth.2014.21

Fortey, R.A. \& Cocks, L.R.M. 2005. Late Ordovician global warming-The Boda event. Geology 33(5), 405-408. DOI $10.1130 / \mathrm{G} 21180.1$

Fuchs, A. 1990. Bemerkungen zu Stratigraphie und Charakter der ordovizischen Conodontenfauna Thüringens. Neues Jahrbuch für Geologie und Paläeontologie 4, 193-214.

Fuganti, A. \& Serpagli, E. 1968. Geological remarks on Urbana Limestone and evidence for its Upper Ordovician age by means of conodonts - Eastern Sierra Morena, South Spain. Bolletino della Società Paleontologica Italiana 87, 511-521.

Furey-Greig, T. 2000. Late Ordovician and Early Silurian conodonts from the "Uralba Beds", northern New South Wales. Alcheringa: An Australasian Journal of Palaeontology 24(2), 83-97. DOI 10.1080/03115510008619526

Ghienne, J.-F., Desrochers, A., Vandenbroucke, T.R.A., Achab, A., Asselin, E., Dabard, M.-P., Farley, C., LOI, A. et Al. 2014. A Cenozoic-style scenario for the end-Ordovician glaciation. Nature Communications 5, art. 4485. DOI 10.1038/ncomms5485

Gutiérrez-Marco, J.C., Aramburu, C., Arbizu, M., Bernárdez, E., Hacar Rodríguez, M.P., Méndez-Bedia, I., Montesinos López, R., Rábano, I., Truyols, J. \& Villas, E. 1999. A biostratigraphical review of the Middle Ordovician shales from NW Spain (Cantabrian and Westasturian-Leonese zones, and northernmost part of the Central Iberian Zone). Acta Geologica Hispanica 34(1), 3-87.

Gutiérrez-Marco, J.C., Arbizu, M., Méndez-Bedia, I., RÁbano, I. \& ARIAS, D. 1996. Equinodermos ordovícicos del noroeste de España, 67-69. In Palacios, T. \& Gozalo, R. (eds) Comunicaciones XII Jornadas de Paleontología.

Gutiérrez-Marco, J.C., Rábano, I., Gómez Moreno, G. \& Hacar Rodríguez, M.P. 1988. Revisión bioestratigráfica de la sucesión ordovícico-silúrica del sector meridional de la zona asturoccidental leonesa (prov. de Orense y León), NO. de España. Resumes X Reunión de Xeoloxía e Minería do N.O. peninsular, A Coruña, 36.

Gutiérrez-Marco, J.C., Robardet, M., Rábano, I., Sarmiento, G.N., San José Lancha, M.A., Herranz Araújo, P. \& Pieren Pidal, A.P. 2002. Ordovician, 31-49. In GibBons, W. \& Moreno, T. (eds) The geology of Spain. Geological Society of London, London. DOI 10.1144/GOSPP.4

Gutiérrez-Marco, J.C., SÁ, A.A., García-Bellido, D.C. \& RÁ-
BANO, I. 2017. The Bohemo-Iberian regional chronostratigraphical scale for the Ordovician System and palaeontological correlations within South Gondwana. Lethaia 50(2), 258-295. DOI 10.1111/let.12197

Hafenrichter, M. 1979. Paläontologisch- Ökologische und Lithofazielle Untersuchungen des "Ashgill-Kalkes" (Jungordovizium) in Spanien. Arbeiten aus dem Paläontologischen Institut Würzburg 3, 1-139.

Hass, W.H. 1959. Conodonts from the Chappel Limestone of Texas. U.S. Geological Survey Professional Paper 294, 365-399. DOI 10.3133/pp294J

Henningsmoen, G. 1948. The Tretaspis Series of the Kullatorp core. Bulletin of the Geological Institut of University of Uppsala 32, 374-432.

Jeppsson, L., Fredholm, S. \& Mattiasson, B. 1985. Acetic acid and phosphatic fossils - a warning. Journal of Paleontology 59(4), 952-956.

Khodalevich A.N. \& Tschernich, V.V. 1973. Novoe podsemeystvo Belodellinae (Konodonty). Trudy Sverdlovskogo Gornogo Instituta 93, 42-47. [in Russian]

KnÜPfer, J. 1967. Zur Fauna und Biostratigraphie des Ordoviziums (Gräfenthaler Schichten) in Thüringen. Freiberger Forschungshefte C220(Paläontologie), 1-119.

Kröger, B., Hints, L. \& Lehnert, O. 2017. Ordovician reef and mound evolution: The Baltoscandian picture. Geological Magazine 154(4), 683-706.

DOI 10.1017/S0016756816000303

LindSTRÖM, M. 1954. Conodonts from the lowermost Ordovician strata of South-Central Sweden. Geologiska Föreningen i Stockholm Förhandlingar 76(4), 517-604.

DOI 10.1080/11035895409453581

Lindström, M. 1959. Conodonts from the Crug Limestone (Ordovician, Wales). Micropaleontology 5(4), 427-452. DOI 10.2307/1484127

LindSTRÖM, M. 1970. A suprageneric taxonomy of the conodonts. Lethaia 3(4), 427-445.

DOI 10.1111/j.1502-3931.1970.tb00834.x

LindSTRÖM, M. 1971. Lower Ordovician conodonts of Europe, 21-61. In Sweet, W.C. \& Bergström, S.M. (eds) Symposium on Conodont Biostratigraphy. Geological Society of America, Memoir 127. DOI 10.1130/MEM127-p21

Martínez Catalán, J.R. 2011. Are the oroclines of the Variscan belt related to late Variscan strike-slip tectonics? Terra Nova 23(4), 241-247. DOI 10.1111/j.1365-3121.2011.01005.x

Mavrinskaya, T.M. \& Yakupov, R.R. 2016. Ordovician deposits of the western slope of the Southern Urals and their correlation based on conodonts and chitinozoans. Russian Geology and Geophysics 57(2), 265-281.

DOI 10.1016/j.rgg.2016.02.004

McCracken, A.D. 1987. Description and correlation of Late Ordovician conodonts from D. ornatus and P. pacificus graptolite zones, Road River Group, northern Yukon Territory. Canadian Journal of Earth Sciences 24(7), 1450-1464.

DOI 10.1139/e87-137

McCracken, A.D. \& Barnes, C.R. 1981. Conodont biostratigraphy and paleoecology of the Ellis Bay Formation, Anticosti Island, Quebec, with special reference to Late Ordovician - 
Early Silurian chronostratigraphy and the systemic boundary. Bulletin of the Geological Survey of Canada 329, 51-134. DOI 10.4095/119430

Melchin, M.J., Mitchell, C.E., Holmden, C. \& Štorch, P. 2013. Environmental changes in the Late Ordovician-early Silurian: Review and new insights from black shales and nitrogen isotopes. Geological Society of America Bulletin 125(11-12), 1635-1670. DOI 10.1130/B30812.1

Müller, K.J. \& Müller, E.M. 1957. Early Upper Devonian (Independence) conodonts from Iowa, Part 1. Journal of Paleontology 31, 1069-1108.

Nance, R.D., Gutiérrez-Alonso, G., Keppie, J.D., Linnemann, U., Murphy, J.B., Quesada, C., Strachan, R.A. \& Woodcock, N.H. 2012. A brief history of the Rheic Ocean. Geoscience Frontiers 3(2), 125-135. DOI 10.1016/j.gsf.2011.11.008

NowLAN, G.S. 1983. Biostratigraphic, paleogeographic, and tectonic implications of Late Ordovician conodonts from the Grog Brook Group, northwestern New Brunswick. Canadian Journal of Earth Sciences 20, 651-671.

DOI 10.1139/e83-060

Nowlan, G.S. \& Barnes, C.R. 1981. Late Ordovician conodonts from the Vauréal Formation, Anticosti Island, Quebec. Geological Survey of Canada Bulletin, 329(Part 1), 1-49. DOI $10.4095 / 119429$

ORCHARD, M.J. 1980. Upper Ordovician conodonts from England and Wales. Geologica et Palaeontologica 14, 9-44.

Paris, F., Pelhate, A. \& Weyant, M. 1981. Conodontes ashgilliens dans la Formation de Rosan, coupe de Lostmarch'h (Finistère, Massif Armoricain). Conséquences paléogéographiques. Bulletin de la Société Géologique et Mineralogique de Bretagne 13(2), 15-35.

Pastor-Galán, D., Gutiérrez-Alonso, G., Murphy, J.B., Fernández-Suárez, J., Hofmann, M. \& Linnemann, U. 2013. Provenance analysis of the Paleozoic sequences of the northern Gondwana margin in NW Iberia: Passive margin to Variscan collision and orocline development. Gondwana Research 23(3), 1089-1103. DOI 10.1016/j.gr.2012.06.015

Rejebian, V.A., Harris, A.G. \& Huebner, J.S. 1987. Conodont color and textural alteration: An index to regional metamorphism, contact metamorphism, and hydrothermal alteration. GSA Bulletin 99(4), 471-479.

DOI 10.1130/0016-7606(1987)99<471:CCATAA >2.0.CO;2

ReXroAD, C.B. 1967. Stratigraphy and Conodont Paleontology of the Brassfield (Silurian) in the Cincinnati Arch Area. Indiana State Department of Natural Resources Geological Survey Bulletin 36, 1-79.

Rhodes, F.H.T. 1953. Some British Lower Palaeozoic conodont faunas. Philosophical Transactions of the Royal Society of London B237, 261-334. DOI 10.1098/rstb.1953.0005

Rhodes, F.H.T. 1955. The Conodont Fauna of the Keisley Limestone. Quarterly Journal of the Geological Society 111(1-4), 117-140.

DOI 10.1144/GSL.JGS.1955.111.01-04.07

Rodríguez-Cañero, R., Jabaloy-SÁnchez, A., Navas-Parejo, P. \& Martín-Algarra, A. 2018. Linking Palaeozoic palaeogeography of the Betic Cordillera to the Variscan Iberian Massif: new insight through the first conodonts of the
Nevado-Filábride Complex. International Journal of Earth Sciences 107(5), 1791-1806.

DOI 10.1007/s00531-017-1572-8

Rodríguez-Cañero, R., Martín-Algarra, A., Sarmiento, G.N. \& Navas-Parejo, P. 2010. First Late Ordovician conodont fauna in the Betic Cordillera (South Spain): a palaeobiogeographical contribution. Terra Nova 22(5), 330-340. DOI 10.1111/j.1365-3121.2010.00954.x

Rodríguez Fernández, L.R., Toyos, J.M., Díez Montes, A., González Menéndez, L., Heredia, N., Rubio Ordóñez, A., Martín Parra, L.M. \& Rubio Pascual, F.L. in press. Mapa Geológico de España E. 1:200.000, hoja n. ${ }^{\circ} 18$ (Ponferrada). Instituto Geológico y Minero de España, Madrid.

Sansom, I.J., Armstrong, H.A. \& Smith, M.P. 1994. The apparatus architecture of Panderodus and its implications for coniform conodont classification. Palaeontology 37(4), 781-799.

Sarmiento, G.N. 1990. Conodontos de la Zona Ordovicicus (Ashgill) en la Caliza Urbana, Corral de Calatrava (Ciudad Real). Geogaceta 7, 54-56.

Sarmiento, G.N. 1993. Conodontos ordovícicos de Sierra Morena (Macizo Hespérico meridional). 598 pp. Ph.D. thesis, Universidad Complutense de Madrid, Spain.

Sarmiento, G.N. 2002. Lower Palaeozoic of the Iberian Cordillera, 281-297. In García-López, S. \& Bastida, F. (eds) Palaeozoic conodonts from northern Spain. Cuadernos del Museo Geominero 1. Instituto Geológico y Minero de España, Madrid.

Sarmiento, G.N., del Moral, B. \& Piçarra, J.M. 2001. Late Ordovician (Ashgillian) conodonts from Serra do Buçaco (Portugal). Coloquios de Paleontología 52, 95-105.

Sarmiento, G.N., Gutiérrez-Marco, J.C. \& del Moral, B. 2008. Conodontos de la "Caliza de Pelmatozoos" (Ordovícico Superior), Norte de Sevilla, Zona de Ossa-Morena (España). Coloquios de Paleontología 58, 73-99.

Sarmiento, G.N., Gutiérrez-Marco, J.C. \& Robardet, M. 1999. Conodontos ordovícicos del noroeste de España. Aplicación al modelo de sedimentación de la región limítrofe entre las zonas Asturoccidental-leonesa y Centroibérica durante el Ordovícico Superior. Revista de la Sociedad Geológica de España 12(3-4), 477-500.

Sarmiento, G.N., Gutiérrez-Marco, J.C., Rodríguez-Cañero, R., Martín Algarra, A. \& Navas-Parejo, P. 2011. A brief summary of Ordovician conodont faunas from the Iberian Peninsula, 505-514. In Gutiérrez-Marco, J.C., RÁBAno, I. \& García-Bellido, D. (eds) Ordovician of the World, Cuadernos del Museo Geominero 14. Instituto Geológico y Minero de España, Madrid.

Savage, N.M. \& Bassett, M.G. 1985. Caradoc-Ashgill conodont faunas from Wales and the Welsh Borderland. Palaeontology 28(4), 679-713.

Serpagli, E. 1967. I Conodonti dell'Ordoviciano superiore (Ashgilliano) delle Alpi Carniche. Bolletino della Società Paleontologica Italiana 63, 1-111.

Stauffer, C.R. 1940. Conodonts from the Devonian and Associated Clays of Minnesota. Journal of Paleontology 14(5), 417-435. 
Stone, J. 1987. Review of investigative techniques used in the study of conodonts, 17-34. In Austin, R.L. (ed.) Conodonts: Investigative Techniques and Applications. Ellis Horwood Limited, Chichester.

SweEt, W.C. 1979. Late Ordovician conodonts and biostratigraphy of the western Midcontinent Province. Brigham Young University Geology Studies 26, 45-86.

Sweet, W.C. 1988. The Conodonta: Morphology, taxonomy, paleoecology and evolutionary history of a long-extinct animal phylum. 212 pp. Clarendon Press, New York.

SweEt, W.C. \& Bergström, S.M. 1984. Conodont provinces and biofacies of the Late Ordovician, 69-86. In ClARK, D.L. (ed.) Conodont Biofacies and Provincialism. Geological Society of America Special Paper 196. DOI 10.1130/SPE196-p69

Sweet, W.C., Ethington, R.L. \& Barnes, C.R. 1971. North American Middle and Upper Ordovician conodont faunas, 163-193. In Sweet, W.C. \& Bergström, S.M. (eds) Symposium on Conodont Biostratigraphy. Geological Society of America Memoir 127. DOI 10.1130/MEM127-p163

Trotter, J.A. \& Webby, B.D. 1995. Upper Ordovician conodonts from the Malongulli Formation, Cliefden Caves area, central New South Wales. AGSO Journal of Australian Geology \& Geophysics 15(4), 475-499.

Villas, E., Vennin, E., Álvaro, J.J., Hammann, W., Herrera, Z.A. \& Piovano, E.L. 2002. The Late Ordovician carbonate sedimentation as a major triggering factor of the Hirnantian glaciation. Bulletin de la Société Géologique de France 173(6), 569-578. DOI 10.2113/173.6.569

VIIRA, V. 1974. Konodonty Ordovika Priblatiki. 142 pp. Eesti NSV Teaduste Akadeemia, Geoloogia Instituudi, Valgus, Tallinn.

Walliser, O.H. 1964. Conodonten des Silurs. Abhandlungen des
Hessischen Landesamtes für Bodenforschung zu Wiesbaden 41, 1-106.

Wang, Z.-H., Zhen, Y.Y., Bergström, S.M., Wu, R.-C., Zhang, Y.-D. \& MA, X. 2019. A new conodont biozone classification of the Ordovician System in South China. Palaeoworld 28, 173-186. DOI 10.1016/j.palwor.2018.09.002

Watkins, R. \& Kuglitsch, J.J. 1997. Lower Silurian (Aeronian) megafaunal and conodont biofacies of the northwestern Michigan Basin. Canadian Journal of Earth Sciences 34, 753-764. DOI 10.1139/e17-062

Zhang, K., Yuan, A. \& Feng, Q. 2018. The Upper Ordovician Microfossil assemblages from the Pagoda Formation in Zigui, Hubei Province. Journal of Earth Science 29(4), 900-911. DOI 10.1007/s12583-017-0958-7

ZHANG, S. 2018. Upper Ordovician conodont biostratigraphy and revised lithostratigraphy and geological map, Akpatok Island, Ungava Bay, Nunavut. Canadian Journal of Earth Sciences 55(1), 52-69. DOI 10.1139/cjes-2017-0145

Zhang, S., Barnes, C.R. \& Jowett, D.M.S. 2006. The paradox of the global standard Late Ordovician-Early Silurian sea level curve: Evidence from conodont community analysis from both Canadian Arctic and Appalachian margins. Palaeogeography, Palaeoclimatology, Palaeoecology 236(3-4), 246-271. DOI 10.1016/j.palaeo.2005.11.002

Zhen, Y.Y. \& Percival, I.G. 2017. Late Ordovician conodont biozonation of Australia-current status and regional biostratigraphic correlations. Alcheringa 41(3), 285-305. DOI 10.1080/03115518.2017.1282982

Zhen, Y.Y., Percival, I.G. \& Molloy, P.D. 2015 Late Ordovician conodonts and brachiopods from near Greenvale in the Broken River Province, north Queensland. Proceedings of the Linnean Society of New South Wales 137, 85-133. 